\title{
Corporate Ownership, Control, and Firm Performance in Victorian Britain
}

\author{
GRAEME G. ACHESON, GARETH CAMPBELL, JOHN D. TURNER AND NADIA VANTEEVA
}

\begin{abstract}
Scholars have long debated whether ownership structure matters for firm performance. The standard view with respect to Victorian Britain is that family-controlled companies had a detrimental effect on operating profit and shareholder value. Here, we examine this view using a hand-collected corporate ownership dataset. Our main finding is that it was not necessarily the broad structure of corporate ownership that mattered for performance, but whether family blockholders had a governance role. Large active blockholders tended to increase operating performance, implying that they reduced managerial agency problems. In contrast, we find that directors who were independent of large family owners were more likely to increase shareholder value.
\end{abstract}

JEL classification: G32, N23

Keywords: Corporate ownership, Performance, Blockholders, Boards of directors

Graeme G. Acheson is Professor of Finance, University of Stirling, Stirling Management School, Stirling, FK9 4LA, Scotland. E-mail: graeme.acheson@stir.ac.uk. Gareth Campbell is Lecturer in Finance, Queen's University Belfast, Queen's Management School, Belfast, BT7 1NN, N. Ireland. E-mail: gareth.campbell@qub.ac.uk. John D. Turner is Professor of Finance and Financial History, Queen's University Belfast, Queen's Management School, Belfast, BT7 1NN, N. Ireland. E-mail: j.turner@qub.ac.uk. Nadia Vanteeva is a Senior Lecturer in Economics, University of the West of England, Bristol Business School, Bristol, BS16 1QY, England. E-mail: Nadia.Vanteeva@uwe.ac.uk.

Thanks to the Leverhulme Trust (Grant no. F/00203/Z) for financial support. Turner also wishes to thank Geoff Jones, Walter Friedman, and Harvard Business School for their hospitality at the outset of this project. Thanks to the archivists at the National Archives at Kew, the National Archives of Scotland, and the Guildhall Library for all their assistance. Thanks to seminar participants at Queen's University Belfast, University College Dublin, the Perth FRESH conference, and the European Business History Association conference for their comments. 
The commonly accepted view amongst scholars is that in the Victorian and Edwardian eras family control of public companies resulted in British public companies performing poorly. It is alleged that they had amateurish and unsophisticated managers, and family owners were more interested in paying out a substantial proportion of company earnings as dividends rather than retaining funds to grow the business (Chandler, 1990, p. 240; Wilson, 1995, p. 154). Indeed, some scholars have even attributed Britain's relative economic decline in the twentieth century to the problems with family-controlled companies (Elbaum and Lazonick, 1984; Chandler, 1990).

Hannah (2007), Foreman-Peck and Hannah (2012) and Acheson et al. (2015) have challenged this conception or caricature of the UK's corporate economy in the Victorian and Edwardian periods as being dominated by family-owned public firms. These studies find that, in many cases, ownership was divorced from control. However, this separation of ownership from control may have created an agency problem, in that the executives of these public companies mismanaged them, and did not run them in the interests of shareholders. Notably, the diffuse ownership structure of British Victorian and Edwardian railways has been highlighted as a contributing factor to their poor performance (Crafts et al. 2007, 2008; Mitchell et al., 2011).

We contribute to this debate by examining the relationship between ownership structure and different measures of firm performance, using hand-collected data for 345 Victorian public companies. This unique dataset enables us to test whether diffuse, or family, ownership affected firm performance.

The idea that ownership structure affects corporate performance has a long academic pedigree. For example, in their classic study, Berle and Means (1932) argued that the separation of ownership from control created an incentive problem in that managers would 
not necessarily act in the best interests of owners. ${ }^{1}$ Large blockholders, which we define as someone who owns 10 per cent or more of the company, may help to reduce this managerial agency problem because they have the incentive and power to monitor managers (Shleifer and Vishny, 1986, 1997). However, blockholders, in turn, may put their own interests ahead of those of minority shareholders (Chandler 1990, p. 292).

Conceptually, directors who are independent of large owners could protect minority shareholders from expropriation by blockholders. However, the perception of boards of directors in the Victorian era is somewhat mixed. A contemporary judge believed that independent directors assured minority shareholders (Kennedy, 1987, p. 126), whereas a contemporary legal writer saw independent directors as incompetent or pre-occupied (Chadwyck-Healey, 1884) or ornamental rather than playing any useful economic function (Campbell and Turner, 2011; Chandler, 1990, p. 242).

Our findings imply that it is not ownership itself which mattered in Victorian Britain, but rather the interaction between ownership and control. Although broad ownership measures are unrelated to firm performance, the presence of large active family blockholders is associated with a better operating performance, as measured by a higher return on assets (ROA). A possible explanation for this is that large active family blockholders in Victorian Britain effectively reduced managerial expropriation by helping to mitigate agency costs. However, this does not translate into greater market values, as measured by Tobin's Q, possibly reflecting minority shareholders' fears of blockholder expropriation. ${ }^{2}$ By way of contrast, the presence of directors who were not blockholders has little effect on operating

\footnotetext{
${ }^{1}$ Lipartito and Morii (2010) question whether Berle and Means (1932) were concerned about the classic agency problem. Rather, they argue that that Berle and Means were more concerned about conflicts between blockholders.

${ }^{2}$ Tobin's Q measures how investors value the company and is widely used as a performance measure in empirical corporate finance studies (Davies et al. 2005; Demsetz and Villalonga 2001). It is the ratio of the market value of the company's common and preferred equity and debt to the book value of the company's assets.
} 
performance but is associated with relatively higher market values. This implies that independent directors in Victorian Britain may have provided credible commitments against family blockholder expropriation, but were less effective at reducing managerial expropriation.

This article also contributes to the literature on the evolution of the UK capital market by looking at control of public companies following the liberalisation of incorporation law in 1856. ${ }^{3}$ To date, the extant literature has focused on the performance and growth of the equity market (Grossman, 2002), the expansion of the investor franchise (Rutterford et al., 2011), and the development of stock exchanges (Thomas, 1973; Michie, 1999). We contribute to the understanding of how the UK capital market transformed from one where shareholders had direct and personal knowledge of a company's operation and management to one where shareholders did not have such personal knowledge. Additionally, this paper augments studies which look at the ownership-performance nexus from an historical perspective. For example, Foreman-Peck and Hannah (2013) find that, for the largest UK companies in 1911, diffuse ownership did not operate against shareholders' interests, suggesting that agency problems were somehow reduced. ${ }^{4}$

Examining corporate ownership structure in the Victorian era is enlightening for contemporary economists because the period under examination was one where the investor protection environment was very weak by modern standards (Campbell and Turner, 2011). ${ }^{5}$ Since investor protection laws can affect ownership structure (La Porta et al., 1998, 1999),

\footnotetext{
${ }^{3}$ On the liberalisation of incorporation law, see Cottrell (1980) and Taylor (2006).

${ }^{4}$ Hilt (2008) looks at New York corporations in the 1820s and finds that the voting power of management is negatively related to firm value.

${ }^{5}$ Statutory companies registered under the Companies Clauses Consolidation Act (1845) scored five out of six in the La Porta et al (1998) anti-director rights index, (Foreman-Peck and Hannah (2015). They are not included in this study. The Companies Act (1862) scored one out of six in the anti-director rights index. All of the companies in our study were registered under this legislation. Nevertheless, there is the possibility that companies registered under the 1862 Act voluntarily adopted anti-director rights in order to list on stock exchanges or attract capital from investors. (see Foreman-Peck and Hannah 2015).
} 
the Victorian period provides us with a natural experiment where we can observe the relationship between structure and performance in a laissez-faire company law regime.

\section{BACKGROUND, HYPOTHESES AND CONCEPTUAL ISSUES}

\section{The liberalisation of incorporation in the $U K$}

Prior to the liberalisation of incorporation law in the middle of the nineteenth century, the right to incorporate in the UK was controlled by Parliament and the Crown. From 1844 onwards, there were a series of acts which made incorporation, and limited liability, easier to obtain. The 1862 Companies Act saw a consolidation of existing pieces of legislation and was the capstone on the liberalisation process. The ownership and control of the companies which incorporated under the 1862 Act, and raised share capital from the market, are the focus of this study.

\section{Manager-owner conflict}

Many of the companies incorporated under the 1862 Companies Act had diffuse ownership (Acheson et al. 2015). Such a separation of ownership from control allows specialisation in share ownership (or residual risk-bearing) and in managerial control (Fama and Jensen, 1983). With the liberalisation of UK incorporation law, this specialisation was available to every firm. However, this specialisation may give rise to an agency problem, in that managers pursue their own interests and do not act in the interests of shareholders (Berle and Means, 1932; Jensen and Meckling, 1976). Examples of managerial inefficiency in the late Victorian era have been highlighted by a number of authors looking at the railway 
industry (Arnold and McCartney, 2005; Crafts et al., 2008; Mitchell et al., 2011). ${ }^{6}$ A possible solution to the managerial agency problem may be provided by monitors who have the incentive to collect information about the firm, and the power to influence managers.

In this study, we categorise the key monitors into three groups: large active family blockholders, large passive blockholders, and directors who are not blockholders. A blockholder is a shareholder controlling more than $10 \%$ of the company. We hypothesise that the presence of large active blockholders will reduce the conflict between managers and owners, and raise profitability as measured by Return on Assets (ROA). These large active blockholders have the incentive and the power to reduce managerial agency costs and raise operating profits. They may run the firm on a day-to-day basis, or at least be closely involved in it, ensuring that all other managers and employees maximise their efforts, and minimise costs. On the other hand, large passive blockholders, with less involvement in the monitoring of managers will not have such an effect.

Directors who are not blockholders often have little impact on the manager-owner conflict. In dispersed-ownership companies, Fama and Jensen (1983) have argued that it is natural that the most influential members of the board will be internal managers as they have the most information about the firm, and they are also well placed to nominate outside directors. Alternatively, the directors may be independent of management, but they do not have the day-to-day involvement in the firm which would be required to reduce the agency problem. Their real influence would be at a strategic level, on major issues which came before the board, not on everyday issues.

To summarise, we use Return on Assets (ROA) as our measure of operating performance to show how efficiently a company uses its assets to earn a profit. The greater

\footnotetext{
${ }^{6}$ Ownership data was not collected by the Registrar of Companies for statutory companies and therefore railways are not included in our sample.
} 
the managerial expropriation, the lower the return on assets. If large active blockholders can reduce managerial expropriation, then, ceteris paribus, ROA will be higher. On the other hand, large passive blockholders and directors who are not blockholders should have had no impact on ROA.

\section{Blockholder-minority shareholder conflict}

Although large active blockholders may be able to discipline managers, they may focus on their own interests and attempt to maximise these at the expense of minority shareholders (Shleifer and Vishny, 1997). This introduces an additional risk factor which investors must consider in their valuations. If they are concerned about expropriation, then the high profitability earned in companies with large active blockholders may not necessarily translate into higher share prices. However, if investors feel protected from expropriation then they may reward the firm with a relatively higher valuation. The blockholder-minority shareholder conflict generally concerns strategic decisions, rather than day-to-day management, and would be typically dealt with at board level. Consequently, having an independent board could help promote good practice and increase shareholder value. Boards with more directors who are not blockholders could be viewed as a commitment that there is a low risk of blockholder expropriation, as collusion would be much more difficult. The result is that, ceteris paribus, valuations (as measured by Tobin's Q) should be higher.

There were numerous ways in which blockholders could put their own interests before those of minority shareholders Firstly, the active blockholder could engage in tunnelling (or related party transations) ${ }^{7}$, by getting the company to lend money at low rates, or buy assets at inflated prices. These would typically affect only the balance sheet, rather than

\footnotetext{
${ }^{7}$ See Gordon et al. (2004) and Cheung et al. (2009). Taylor (2013, pp.215-7, 223) notes several examples of this type of practice.
} 
profitability, in the short-term. Another form of tunnelling can occur when the blockholder gets the company to trade with other firms that he owns. The company is then charged inflated prices and the benefits are earned by the blockholder's other firms, at the expense of the minority shareholders. Even if this did not occur immediately but investors understood that it could occur in the future, it would mean that current profitability could remain high, but the share price would be discounted to reflect the additional risk. An example of this type of tunnelling was seen in the case of the Grosvenor Hotel; R. C. Drew was the largest shareholder and exercised control over a small board, who colluded with him to obtain most of the supplies for the hotel from a butcher, grocer, and laundry all owned by Drew. ${ }^{8}$

Blockholders could also put themselves first by withholding information. As insiders, they had detailed knowledge about the performance of the firm, which they could use to inform their decisions on whether to buy or sell stock in it (insider trading). They could deny much of this information to others, placing the minority shareholders at a disadvantage. For example, The Financial Times remarked about the Globe Cotton Spinning, a company in our sample, that it paid a dividend by forwarding 'a cheque to each shareholder for whatever amount may be due to him at a rate the Directors fix on ... Apparently no accounts are circulated ... No information is obtainable beyond the capital subscribed and a few office particulars'. ${ }^{9}$ This secrecy would tend to raise the risk for minority shareholders, and lower valuations, despite the profitability of the company.

Active blockholders could also continue in their position within the company, even when it was no longer performing well. The removal of a large active blockholder, as managing director, would likely have been much more difficult than the removal of someone who was not a blockholder. The Financial Times reported on the Aylesbury Dairy implying

\footnotetext{
${ }^{8}$ Financial Times, Feb 21, 1898, p. 7.

${ }^{9}$ Financial Times, 23 Jan 1901, p. 4.
} 
that the severe difficulties it faced were related to the past decisions of its active blockholder, G.M. Allender, who it referred to as the 'Life Managing Director' ${ }^{10}$ A similar problem could arise if the active blockholder used his power to appoint some of his family as his replacement. In a similar vein, if there was a risk that the blockholder would engage in empire-building, it could be detrimental to shareholder value. Foreman-Peck and Hannah (2015, p.20) note the example of Samuel Waring who engaged in a disastrous expansion and acquisition plan with the furniture company Waring \& Gillow. Finally, and most blatantly, the active blockholders could attempt to deceive the minority shareholders by falsifying financial statements, to attract capital.

The potential for these abuses by large active blockholders, even if they did not materialise, raised the risks faced by minority shareholders. We hypothesise that even though large active blockholders may raise profitability (ROA), they do not necessarily raise firm value (Tobin's Q). Large passive blockholders, who have no effect on profitability, should have no effect on value, because they do not exercise enough power to engage in expropriation. However, having a board with many directors who are not themselves blockholders will significantly increase the value of the firm, as collusion on expropriation would be much more difficult. If their focus is on major strategic decisions, rather than the minutiae of day-to-day decisions, such directors may have little influence on profitability, but they can provide safeguards against systematic expropriation.

\footnotetext{
${ }^{10}$ Financial Times, Nov 16, 1891, p. 2. Guinnane et al. (2014) have found that 26.2 percent of their sample of mainly private companies 'specified in their articles that certain named directors would serve for a long period of years or even for life'.
} 


\section{Empirical framework}

We examine the relationship between the governance structure and performance of non-statuatory public companies in Victorian and Edwardian England. Our estimating equation takes the form

$$
\text { Performance }=\propto+\beta_{1} \text { Governance }+\beta_{2} \text { Controls }+\beta_{3} \text { YearDummies }+\varepsilon
$$

We use ROA and Tobin's Q as performance measures, and the dependent variables, in our post-1880 performance sample. ROA is measured as:

$$
R O A=\frac{\text { Profits }}{\text { BV Assets }}
$$

and Tobin's Q is calculated as follows:

$$
Q=\frac{M V E q+\text { Pref }+ \text { Debt }}{B V \text { Assets }}
$$

where MVEq = year-end market value of firm's common stock; Pref = year-end value of firm's preferred stock; Debt = year-end value of firm's total debt; and BV Assets = total assets of firm. Controls on age, size, location, growth, industry, ownership structure and corporate control measures are described in the next section.

The main threat to validity which has been identified in studies of ownership structure is that of causality: does ownership structure affect performance or performance ownership structure (Cho, 1998; Demsetz and Villalonga, 2001). Demsetz and Villalonga (2001, p.221) argue that 'compensation plans, insider trading possibilities, and corporate takeovers suggest that firm performance may influence ownership structure as well as be influenced by it'.

However, there are several reasons to believe that reverse causality in a Demsetz and Villalonga world was not a major issue in the Victorian context. Even if some related-party transactions or tunnelling could be seen as affecting compensation, directors in our firms were paid said salaries and performance related bonuses, none of which resulted directly in 
changes of ownership, unlike modern equity-based plans. Second, hostile takeover bids and accumulation of stakes by potential acquirers were very rare in this era (Cheffins 2008, p. 79; Hannah 1974; Hannah 1976, p. 150; Hannah 2011, p. 241). Third, Braggion and Moore (2013) find that while insider trading was not illegal, it rarely happened (Braggion and Moore, 2013). Fourth, institutional investors were very small players and typically only invested in fixed-interest securities such as corporate and government bonds, not equities (Cheffins, 2008, p. 190; Raynes, 1928). ${ }^{11}$

Indeed, in the Victorian context, it was difficult for changes in ownership structure to occur quickly, as stock was often not as actively traded. ${ }^{12}$ This meant that large one-off changes in ownership structure were not possible. We are not suggesting that blockholder changes were uncommon. However, it would have taken investors a long time to accumulate a block-holding stake in a company to fundamentally alter the ownership structure.

The absence of such mechanisms does not completely eliminate the reverse causality issue. One potential source of reverse causality is where a blockholder may be more likely to take a position on the board when companies are more profitable. In a robustness check, we find very little evidence of large passive blockholders rotating in or out of directorships, but we cannot conclusively rule this possibility out. However, it could be argued that blockholders might be more likely to take a seat on the board if profitability was low and the company was not performing well, in the hope of improving performance. A finding that active blockholders are associated with high profitability runs counter to what would be expected from results driven by endogeneity.

As an additional robustness check, we use a different measure of performance which should be less prone to the reverse causality problem, namely firm outcome. It seems

\footnotetext{
${ }^{11}$ We found 64 different investment trusts who owned shares in our sample, but their shareholdings were small.

${ }^{12}$ For example, the median number of trades per annum in the 1870s for the 14 UK banks reported in Acheson and Turner (2008, pp.136-7) is only 53 i.e., one share trade per week. Also, stock repurchases were extremely uncommon prior to 1887, when they became illegal (Turner et al., 2013).
} 
plausible that ownership structure could affect the final status of the company. However, it is unlikely that the future state of the company would affect current ownership. Firm outcome differs from our other measures of performance, ROA and Tobin's Q, in that conceptually, we are measuring performance or success purely in terms of survival (Alchian, 1950). We are posing the following two questions: (a) Was a specific type of ownership structure a survivable trait of firms over the long run? (b) Did a certain type of ownership structure make it more likely for a firm to fail for explicit performance reasons? ${ }^{13}$

Although reverse causality should not be a major issue in this analysis, there may be unobserved factors that jointly cause performance and ownership structure. There may also be issues in terms of whether certain conditions led to different ownership configurations. For example, a firm founder who was likely to obtain high rents, and therefore high ROA, may keep a large block of shares to extract as much value as possible. The founder of a firm with high capital expenditures, and who needed to repeatedly raise more capital from minority shareholders, would be more likely to initially configure the firm with independent directors. For firms which were expected to be more successful, there may have been stronger demand for shares from subscribers, so that ownership became less concentrated. These issues mean that, ultimately, the most that we can say about any relationships we find is that they are correlations, and do not necessarily imply causality.

\section{DATA}

\section{Sample}

Our main sources of ownership data are the Companies Registration Office files held at the National Archives in London (BT31 series) and the National Archives of Scotland

\footnotetext{
${ }^{13}$ This is in the spirit of Fama and Jensen (1983) who see firms or organisations not surviving if they select the wrong ownership structure at their origin.
} 
(BT2 series). Companies registered under the 1856 and the 1862 Companies Act were required to return a list of their ordinary and preference shareholders to the Registrar of Companies annually. Up until 1970, whenever a company was dissolved in the UK, its ownership records were placed within the Companies Registration Office files. ${ }^{14}$

Because we are interested in the ownership of publicly-listed companies, we collected the names of all UK companies issuing common stock between 1862 and 1900 from the Course of the Exchange (COE) and the Investor's Monthly Manual (IMM). Unfortunately ownership returns were extensively weeded by archivists so that, for any one firm, only a small sample of years was preserved. We collected ownership returns for 1865, 1870, 18801884,1890 and 1900 or one or two years either side of these sample years if the return existed. If a company had ownership returns which fell outside the selected sample years, we collected a return for each decade between 1860 and 1900, where available.

The ownership returns report the cash-flow rights of shareholders, but not the voting rights of shareholders or the names of directors. We therefore hand collected data on each company's voting rights for each year for which we had an ownership return from Burdett's Official Intelligence (BOI), Stock Exchange Official Intelligence (SEOI) or a company's articles of association, usually available with the ownership returns. The names of directors for the relevant years were obtained from the same sources. In order to ascertain the share ownership of each director, we manually checked each set of ownership returns.

As noted above, we use three performance measures. The accounting data to calculate Tobin's Q and ROA comes from Burdett's collection of company accounts stored in the Guildhall Library in London, whilst the market value of the firm's securities is obtained from

\footnotetext{
${ }^{14}$ Most nineteenth-century companies registered under these two Acts dissolved. Their ownership records, if they survived, are in these archives.
} 
the December issue of the relevant $I M M .^{15}$ As Burdett's accounting data is only available from 1880 onwards, our first sample is restricted to the post-1880 period and contains 252 firm-years, consisting of 186 unique firms, 11 with three observations, 44 with two observations, and 131 with one observation. 34.1 per cent of our sample comes from the $1880 \mathrm{~s}, 40.5$ per cent from the $1890 \mathrm{~s}$, and 25.4 per cent from 1900-1901. The four most represented industry sectors, as shown in Appendix 1, are industrial and commercial firms comprising 25.8 per cent of our sample, banks comprising 15.5 per cent, mortgage and finance companies comprising 13.9 per cent, and iron, coal and steel companies comprising 12.3. The remainder of the sample is spread across eight other industry sectors. We obtain survival/failure date from the Register of Defunct Companies, which lists any company delisted from the stock exchange from 1875 onwards with the reason for delisting. ${ }^{16}$ We are able to trace the year of delisting as well as the ultimate fate of 344 companies.

Compared to the total population of publicly-quoted companies listed in $B O I$, our sample is a relatively small proportion. According to Essex-Crosby's data, there were 1,585 and 2,581 non-railway companies listed in 1885 and 1895 respectively (Jefferys 1977, p. 458). In terms of the number of unique companies quoted in the $C O E$ and $I M M$ between 1862 and 1901, we estimate that there were 2,664 companies excluding railways, quoted at some point during this period. In Appendix 1, we present a detailed breakdown of how our sample compares to non-railway companies listed in the IMM. The median par value of $I M M$ firms in 1880 was $£ 150,000$ and in 1900 was $£ 250,000$. Our performance data sample firms have a median par value of $£ 150,000$, whilst our final status sample firms have a median par value of $£ 133,099$, implying that our sample is more weighted towards small and medium-sized public companies. When compared to all of the non-railway companies in BOI, which included

\footnotetext{
${ }^{15}$ Because the $I M M$, does not contain the market value of some corporate bonds or preferred shares, we have to resort to using their book values as per Davies et al. (2005).

${ }^{16}$ We use the London Gazette and Edinburgh Gazette as supplementary sources.
} 
more of the small firms, our sample is fairly representative. The average paid-up capital of our companies for the ROA and Tobin's Q sample is $£ 256,700$, and for the final status sample is $£ 216,560$, which are similar to the average paid-up capital of non-railway companies in $B O I$ in 1885 and 1895 , which were $£ 209,752$ and $£ 262,340$ respectively (Jefferys 1977, p. 458).

There were some substantial changes in industrial composition during this period, as seen from Appendix 1, but the only industry which seems to be under-represented in our sample in both 1880 and 1900 is mining. The commercial and industrial sector, which consisted mainly of manufacturing and processing companies, is the largest sector in our sample, which is unsurprising since this was a growth sector in the stock market (Grossman 2002, p. 130). In terms of those listed in BOI, our sample under-represents the commercial and industrial sector and over-represents banking. This is again unsurprising because banks were more likely than other companies to have a large shareholder base and have their shares traded on public markets, whereas industrial and commercial public companies were more likely to be small and not regularly traded.

\section{Ownership variables}

The richness of our data permits a wide variety of measures of ownership structure. Following Demsetz and Lehn (1985) and Demsetz and Villalonga (2001), we look at the ownership of the five largest shareholders as this may proxy the ability of shareholders to control managers. We can also construct a Herfindahl Index of ownership. We describe ownership by the board of directors as a whole, and of insiders which embraces both directors and blockholders. We then split this insider category into three types of individuals. Large active blockholders (i.e., individuals who owned more than 10 per cent of capital or voting rights and were on the board), large passive blockholders (i.e., individuals who owned more 
than 10 per cent of capital or voting rights and were not on the board), and directors who were not blockholders. The variables are described in Appendix 2.

$$
<<\text { Insert Table } 1>>
$$

Summary statistics are presented in Table 1, VoteLargest 5 and VoteHHI variables both indicate that corporate ownership was relatively diffuse in our sample. Notably, the average of the VoteLargest 5 variable at 21.44 per cent is very similar to the capital owned by the five largest shareholders in modern studies (e.g., Demsetz and Villalonga, 2001; Davies et al., 2005; and Maury, 2006). In our regression analysis, we take log values of VoteLargest5 and VoteHHI to obtain symmetric distributions. Directors, on average, control a fairly small proportion of voting rights in our sample, with the averages of VoteDir being 11.53 per cent, not dissimilar to that reported by Foreman-Peck and Hannah (2012) for the largest 337 British firms in 1911. We also summarize the ownership of large active blockholders who were directors, the ownership of large passive blockholders who were not directors, the ownership of directors who were not blockholders, and the ownership of all insiders i.e., directors plus large blockholders. The mean and median of VoteInsiders, which measures the votes of both directors and large shareholders, are 14.38 and 9.06 per cent respectively. ActiveBlock and PassiveBlock averages imply that a minority of firms had someone who was a large blockholder. However, the mean votes controlled by those blockholders was 24.87 per cent, and for those firms that had a passive blockholder, the mean votes controlled by those blockholders was 24.90 per cent. The DirOnlyVote variables show that directors who were not large blockholders, on average, held a total of 7.78 per cent of voting rights between them. 
Although not reported separately, there is little difference between the concentration of capital and voting, and, if anything, voting is slightly less concentrated than capital. Many companies had voting regimes with caps limiting the total votes of each investor or which skewed the voting scale in favour of small investors and discriminated against large shareholders (Campbell and Turner, 2011). ${ }^{17}$

In Table 2 we describe how ownership by directors and large blockholders varies across industry. Four things are worthy of note. First, very few firms in any sectors had large blockholders. Second, there was a very small propensity for directors to be large blockholders, but a higher propensity (60.5 per cent) for large blockholders to be directors, which implies that the majority of such shareholders wanted to maintain control over the company. Third, the vast majority of directors were not blockholders, with the average board having 6.1 directors and, on average, 5.9 of these were not large blockholders. Fourth, there is some variation across industries in terms of the percentage of voting rights controlled by large blockholders, with breweries, iron, coal and steel companies, and industrial and commercial companies having higher blockholder ownership than other industries. ${ }^{18}$

\section{$<<$ Insert Table 2>>}

\section{Performance variables}

As noted above, the main performance measures are ROA and Tobin's Q. In our regression analysis, we winsorize each of the variables at the $1^{\text {st }}$ and $99^{\text {th }}$ percentiles to deal

\footnotetext{
${ }^{17}$ Such voting regimes were common elsewhere in this period (Hilt, 2008, 2013; Pargendler and Hansmann, 2013; Musacchio, 2009).

${ }^{18}$ Perhaps the high levels of fixed and firm-specific assets meant that there was less need for large owners to commit to other stakeholders by having a greater separation of ownership from control (Mayer, 2013) because the infungible assets meant that it was more difficult to expropriate employees, suppliers, creditors, and customers, thereby reducing the need for large owners to credibly commit to these stakeholders by separating ownership from control.
} 
with outliers and use industry-adjusted Tobin's Q and industry-adjusted ROA whereby Tobin's Q, and ROA are adjusted using industry averages as per the industrial sectors in Table $2 .^{19}$

Our robustness check on performance is firm status. The Register of Defunct Companies explains why firms delisted. We use this information to create variables about the ultimate fate or final status of our sample companies. We find that 41 per cent of firms merged with other companies and disappeared as separate entities; 5 per cent of firms were wound up by court orders; 15 per cent of firms were removed from the stock exchange yearbook; 24 per cent of firms were voluntarily wound up by their shareholders; 16 per cent of firms were reconstructed (see Table 1)

In terms of ex ante optimality for shareholders, if a firm were to disappear, the worst outcome would have been a court order to wind up, followed by a voluntary winding up. In the former, larger losses would usually have been incurred by shareholders, whereas the losses may not have been as severe in the case of a voluntary winding up. Removal from the Stock Exchange Yearbook usually occurred because a firm had failed, which again suggests poor performance. The best outcome would be a merger. The extensive rationalisations and merger movements in many of the industries at the turn of the twentieth century (Sykes, 1926; Supple, 1970, pp. 273-96; Hannah 1974, 1976) suggest that few mergers were for explicit performance reasons. Reconstruction of companies also does not necessarily imply performance issues with firms, and would lie between the best outcome (i.e., merger) and the worst outcomes (i.e., winding up or removal). ${ }^{20}$

\footnotetext{
${ }^{19} \mathrm{We}$ also run our regressions with unadjusted measures and industry dummies, but this does not change our results.

${ }^{20}$ This involved raising new capital or reorganising existing capital or, sometimes, renaming and re-registering the firm.
} 
We include two variables to capture governance and control, Board size (NumDir) ranged from 3 to 23 , with a mean and median of $6.0 .^{21}$ Independence is captured by the number of directors who are not also large blockholders (DirOnlyNum) and ranges from 2 to 23 , with a mean of 5.8 and median of 5.0 (See Table 1).

We use the establishment year of the company to capture the maturity of the firm (EstDate). We control for cyclical variations in ROA and Tobin's Q by using dummies for the years in which the data was obtained, and capture a time effect (OwnDate) for the final status of the company. We control for firm size by including the natural logarithm of a firm's paid-up capital in our regressions (Size) and a leverage ratio (LTDebt). ${ }^{22}$

Since directors in this era were usually required to own a certain number of shares, which was usually low relative to the capital of the firm (Campbell and Turner, 2011), we include a director qualification variable (DirectorQual) because this may have affected the relationship between ownership and performance. The mean, median, and range suggests that director qualifications were not a high proportion of the firm's par (paid-up) capital. Indeed, on average, 29.3 per cent of shareholders had enough shares to qualify as a director.

We also control for whether or not a firm had London headquarters because such firms may have had greater access to capital markets and oversight by professional investors (HeadLondon). As our data comes from two different archives, we control for any possible effect this might have on the relationship between ownership and performance by including a binary variable which takes the value of one if our firm was Scottish, zero otherwise. In our regressions where ownership is regressed on Tobin's Q, we also control for the return on

\footnotetext{
${ }^{21}$ After removal of $1^{\text {st }}$ and $99^{\text {th }}$ percentiles

${ }^{22}$ The mean and median leverage ratios in Table 1 are low compared to the Essex-Crosby data for all companies listed in BOI in 1885 and 1895, where the respective averages are 20.7 and 29.0 per cent (Jefferys 1977, p. 458). There are at least two reasons for this. First, we have an over-representation of banks and other financial companies which did not have long-term debt in their capital structure. Second, some public companies, such as breweries, issued only debentures to the public and are therefore not in our sample, but are included in the Essex-Crosby figures.
} 
assets $(R O A)$, allowing us to analyse the determinants of firm value after controlling for differences in operating performance.

\section{THE RELATIONSHIP BETWEEN OWNERSHIP AND PERFORMANCE}

Table 3 contains pairwise correlations between our performance and ownership variables. Although there is a positive correlation between Q and ROA, they are not highly correlated, suggesting that they are measuring different aspects of firm performance. Second, ActiveBlock is positively correlated with ROA, implying having directors with more than 10 per cent of the capital are associated with higher accounting profits. Third, there is a positive correlation between Tobin's Q and DirOnlyNum, implying that boards with more directors who are not also large blockholders are associated with a higher Tobin's Q.

In Table 4, we show the results for various specifications of voting concentrations on ROA (panel A) and Tobin's Q (panel B). VoteLargest5 and VoteHHI, are uncorrelated with ROA implying that ownership structure, in a very broad sense, is unrelated to operating performance as measured by ROA. However, the positive coefficient on the VoteDir variable, which remains even when control variables are introduced, suggests that greater ownership in the hands of directors is associated with higher ROA. In panel B, we find a suggestion of a negative relationship between the broad ownership measures and Tobin's Q, but only one of the ownership measures is weakly significant.

$<<$ Insert Tables $3 \& 4>>$ 
The results also reveal that NumDir (board size) has little effect on ROA, but a highly significant positive effect on Q. One interpretation is that larger boards may have acted as a check on large blockholders expropriating minority shareholders, and was therefore valued by them. Overall these results imply a complex relationship between ownership by large shareholders, ownership by directors, and the number of directors. ${ }^{23}$

To analyse the interaction between these factors more precisely, each insider is categorised as either an active blockholder, a passive blockholder, or a director who was not a blockholder. We begin with a simple difference-in-means test between companies with and without each type of blockholder, and above and below median numbers of individuals who were solely directors. (See Table 5). We classify a blockholder as having 10 per cent of voting rights, but since our findings may be sensitive to this definition, we check the robustness of our results using 5 and 20 per cent levels (see Holderness, 2009, p. 1399). The ROA for companies with at least one active blockholder is statistically and economically greater than that for companies without, irrespective of what definition of large blockholder we use. In addition, Tobin's Q for companies with above median number of individuals who were solely directors is statistically greater than that for companies below the median for all three definitions. ${ }^{24}$

\section{$<<$ Insert Table 5>>}

In Tables 6 and 7, we refine our analysis of the interaction between performance and governance. The most noteworthy finding in Table 6 is the positive and statistically

\footnotetext{
${ }^{23}$ The ownership concentration measures are based on voting rights. For the sake of robustness, we also use cash-flow rights as a measure of ownership concentration and find that the results, are similar to those in Table 4.

${ }^{24}$ Changing the definition of a large shareholder to someone holding five per cent of stock creates a substantial increase in the number of individuals classified as large blockholders, with the 20 per cent definition reducing them.
} 
significant coefficient on ActiveBlock, which implies that firms with blockholders who are also directors perform better in terms of ROA than other firms. The coefficient on ActiveBlock suggests that a one per cent increase in the votes of active blockholders increases ROA by about 0.3 per cent. This is consistent with the idea that such owners have the incentives and power to make sure than the firm is efficiently run to produce a high ROA.

Previous research has indicated that the relationship between ownership and performance may be non-linear (Morck et al., 1988 and McConnell and Servaes, 1990), so we include a squared term (ActiveBlockSq). The results indicate that ActiveBlockSq is significant and negative, indicating that active blockholder ownership is beneficial up to a point, but may become less useful at very high levels. Differentiating and solving suggests that the optimum level of active blockholder ownership is 27.1 per cent. Because the difference between voting rights and cashflow rights may be influential (Claessens et al., 2002 and Gompers et al., 2009), we include the ActiveCashWedge variable, which calculates cashflow rights minus voting rights for active blockholders. This is not significant. In robustness regressions, reported later, we find that using capital concentration does not change the results.

We go further, attempting to determine whether the active blockholders were fulfilling the role of the primary manager, essentially acting as a CEO ${ }^{25} \mathrm{We}$ assume that the Chairman fulfils the role of a modern CEO, unless another Managing Director (MD) is named in which case that person is seen as CEO. In our sample, we have 34 firm-years with active blockholders where either the Chairman and/or MD is named. Of these, in 18 firmyears the role of CEO was taken on by the active blockholder. These could be thought of as family firms, where the largest owner was also the manager. To investigate their impact on

\footnotetext{
${ }^{25}$ With few cases where anyone is identified simply as Manager, we used judgement as to what different titles actually meant.
} 
performance, we split our ActiveBlock variable into two parts, ActiveCEOBlock and ActiveNotCEOBlock, and re-run the regressions (see column 7 of Table 6). We find that both have a similar positive and significant impact on ROA.

$<<$ Insert Tables $6 \& 7>>$

Despite the positive impact that active blockholders have on ROA, there appears to be an insignificant relationship between ActiveBlock and Tobin's Q, (Table 7), implying that minority shareholders do not value having a large blockholder who is also a director. The coefficient on the PassiveBlock variable suggests that large shareholders who do not take on a monitoring role have little effect on performance or firm value.

Having directors who are not blockholders (DirOnlyNum) has no effect on ROA, but it has a positive and significant effect on Tobin's Q, which implies that the number of directors who are not blockholders matters. The size of the coefficient implies that adding one more independent director increases Tobin's Q by about 0.03 (See Table 7). This would imply that a company which started with the average Tobin's Q of 0.94 could increase it to 0.97 , meaning that firm value would rise by about 3.2 per cent by adding another independent director. This finding is consistent with the view that an independent board may play a role in constraining large blockholders from expropriating small shareholders.

We also reformulate our DirOnlyNum variable into two parts, with variables for both the total number of directors (NumDir) and the proportion of the board who are active blockholders (PropDirBlock). This approach may suffer from a multi-collinearity problem as the correlation between ActiveBlock and PropDirectorsBlock is 0.857 . The issue is similar if we use the proportion of directors who are not blockholders, just the direction of correlation is reversed. The results suggest again that having a greater number of directors is 
significantly and positively related to Tobin's Q (see column 8 of Table 7) which is consistent with the view that collusion is more difficult in larger groups. Having a larger board appears to make it more challenging to expropriate shareholders.

The ActiveCashWedge variable, which had no effect on ROA, does not have a significant impact on Tobin's Q. These results are interesting because they suggest that voting rights that limited the power of large shareholders might not have been important covariates of valuation. One potential explanation is that most company constitutions permitted voting at AGMs to be by a show of hands and the complicated voting weights would only be applied if specifically requested, which may have somewhat attenuated the power of voting schemes which limited the power of large shareholders. In addition, there was a rapid decline in AGM attendance in Victorian Britain (Jefferys 1977, p. 396), which may have further blunted the power of voting schemes. The lack of influence of voting powers stands in contrast to the positive impact of independent directors. This is likely because it was the directors who were responsible for making almost all strategic decisions, with a vote at a company meeting usually only called to ratify what the directors had suggested.

We carry out a series of robustness checks using alternative cutoff levels for a large blockholder. We consider cutoff points at the 5, 10 and 20 per cent levels, using both voting concentration and capital concentration measures. In Table 8 where ROA is the dependent variable, there are positive and statistically significant coefficients on ActiveBlock. This confirms that large blockholders who are also directors have a positive effect on operating performance, and this finding is robust to alternative definitions of what constitutes a large blockholder. Table 9 reveals that the relationship between the DirOnlyNum variable and Tobin's Q is not affected by changing the definition. 
As a further robustness check, we consider whether large passive blockholders in this study may have been rotating in and out of a directorship and therefore may have actually been active blockholders. To ensure this is not the case, we check all such blockholders for two years either side of each observation, using the Stock Exchange Yearbook and Directory of Directors, and find only three examples of a large passive blockholder being a director in this window. Where we have multiple observations, we also conducted analysis for those companies, which either gained or lost an active blockholder. We have three occasions where the company gains an active blockholder. The average increase in ROA is 7.9 percentage points. At the same time, Tobin's Q declines 0.18. We have five occasions where the company loses an active blockholder. The average decline in ROA is 4.2 percentage points, and an average increase in Tobin's Q of 0.10 . These results are exactly in line with our hypotheses and our empirical results. However, given the small sample sizes, we do not want to put too much emphasis on these findings. Our results are also robust to the exclusion of banks and insurance companies. ${ }^{26}$

As noted earlier, we use the final status of the company as a dependent variable to carry out a further robustness check. We use multinomial logit regressions to examine how ownership affects the ultimate fate of the company. The results shown in Tables 10 and 11 reveal whether ownership structure made a company more or less likely to experience a particular outcome, relative to the base outcome which we have chosen as merging with another firm.

The first thing to note from Table 10 is that there is little statistical or economic relationship between broad ownership structure, as measured by VoteHHI, and the final status

\footnotetext{
${ }^{26}$ Contact authors for results.
} 
of the company; only VolWoundUp is significant and only at the 10 per cent level. Using different measures of ownership structure, give similar results and are not reported separately. The proportion held by insiders (VoteInsiders) is only significant against VolWoundUp, whilst the proportion held by the five largest shareholders (VoteLargest5), or by directors (VoteDir), are not significant predictors of any outcome. The negative coefficient on NumDir in specifications 2 and 3 suggests that the greater the number of directors a company had, the less likely they were to be wound up by a court, or to be removed from the stock exchange.

$<<$ Insert Tables $10 \& 11>>$

In Table 11 we examine the interaction of final status and director/blockholder interactions. We find negative coefficients on the DirOnlyNum variable for those companies whose ultimate fate was to be wound up by a court or removed from the Stock Exchange Yearbook, implying that the greater the number of directors who were not large blockholders, the less likely that the company was to experience failure. In addition, the presence of large active blockholders is correlated with a lower probability of a company experiencing a negative ultimate outcome, although the coefficient on the ActiveBlock variable is only significant at the 10 per cent level. This would again suggest, consistent with the previous results, that the presence of a large active blockholder may have a positive influence on how the firm operates.

We also conducted a survival analysis to examine if any of the governance variables had an impact on how long the company survived independently. However, none of the governance variables were significant, possibly because a large proportion of our sample companies ended by merging with another firm, or being acquired. This makes it difficult to 
interpret survival time, as companies which merged quite early did not necessarily have poor performance.

In summary, the results suggest that the presence of someone who is both a large shareholder and a director is associated with a higher ROA and less likelihood of experiencing a negative future state, but it does not result in a higher Tobin's Q. This implies that large active blockholders alleviate managerial agency problems and have a desire for survival in the long run, but their presence is not necessarily valued by other shareholders. The number of directors who are not large shareholders is positively correlated with a higher Tobin's Q and a lower probability of failure in the long run, which may imply that they were effective at preventing expropriation by large shareholders.

\section{CONCLUSION}

This paper has addressed the debate of whether ownership structure mattered for firm performance in Victorian Britain. Our basic finding is that it was not the broad structure of corporate ownership which mattered for the performance of Victorian public companies, but whether a family blockholder had a governance role. Our results suggest that large family blockholders who were directors ensured that firms were well run and alleviated managerial agency problems. However, minority shareholders in Victorian Britain appear not to have placed a high value on such firms, possibly because of the potential threat of expropriation. Indeed, minority shareholders seemed to prefer boards dominated by independent directors and not by large shareholders. This implies that independent directors played a useful economic function in Victorian Britain and were not just ornamental.

Firms dominated by family blockholders were relatively uncommon before the 1890 s, as many public companies launched on the stock market from scratch before that time. However, blockholders became much more common from the 1890 s onwards as the newlylisted firms in this era were typically conversions of long-established firms, which had 
previously been partnerships (Acheson et al., 2015; Cheffins, 2008, p. 181). The implications of this change in the nature of stock-market flotation for British capital markets and economic development are something to be addressed in future research.

\section{References}

Acheson, Graeme G. and John D. Turner. "The Secondary Market for Bank Shares in Nineteenth-Century Britain.” Financial History Review 15, no. 2 (2008): 123-51.

Acheson, Graeme G., Gareth Campbell, John D. Turner and Nadia Vanteeva. "Corporate Ownership and Control in Victorian Britain." Economic History Review 68, no. 3 (2015): 911-36.

Alchian, Armen A. "Uncertainty, Evolution, and Economic Theory." Journal of Political Economy 58, no. 3 (1950): 211-21.

Arnold, A. J. "Should Historians Trust Late Nineteenth-Century Company Financial Statements?" Business History 38, no. 2 (1996): 40-54.

Arnold, A. J., and Sean McCartney. "Rates of return, Concentration Levels and Strategic Change in the British Railway Industry, 1830-1912." Journal of Transport History 26, no. 1 (2005): 41-60.

Atanasov, Vladimir. "How Much Value Can Blockholders Tunnel? Evidence from the Bulgarian Mass Privatization Auctions." Journal of Financial Economics 76, no. 1 (2005): 191-234.

Bebchuk, Lucian A., Martijn Cremers and Urs Peyers. "The CEO Pay Slice." Journal of Financial Economics 102, no.1 (2011): 199-221.

Berle, Adolf A. and Gardiner C. Means. The Modern Corporation and Private Property. New York: Macmillan, 1932.

Braggion, Fabio and Lyndon Moore. "How Insiders Traded Before Rules." Business History 55, no. 4 (2013): 565-84.

Burdett's Official Intelligence (1882-1902).

Campbell, Gareth and John D. Turner. "Substitutes for Legal Protection: Corporate Governance and Dividends in Victorian Britain." Economic History Review 64, no. 2 (2011): 571-97.

Chadwyck-Healey, C. E. H. A Treatise on the Law and Practice Relating to Joint Stock Companies Under the Acts of 1862-1883. London: W. Maxwell \& Son, 1884. 
Chandler, Alfred D. Scale and Scope: The Dynamics of Industrial Capitalism. Cambridge, MA: Belknap Press, 1990.

Cheffins, Brian R. Corporate Ownership and Control: British Business Transformed. Oxford: Oxford University Press, 2008.

Cheung, Yan-Leung, P. Raghavendra Rau and Aris Stouraitis. "Tunneling, Propping, and Expropriation: Evidence from Connected Party Transactions in Hong Kong." Journal of Financial Economics 82, no. 2 (2006): 343-386.

Cheung, Yan-Leung, Yuehua Qi, P. Raghavendra Rau, and Aris Stouraitis. "Buy High, Sell Low: How Listed Firms Price Asset Transfers in Related Party Transactions." Journal of Banking and Finance 33, no. 5 (2009): 914-924.

Cho, Myeong-Hyeon. "Ownership Structure, Investment and the Corporate Value: An Empirical Analysis.” Journal of Financial Economics 47, no. 1 (1998): 103-21.

Claessens, Stijn, Simeon Djankov, Joseph P. H. Fan and Larry H. P. Lang. "Disentangling the Incentive and Entrenchment Effects of Large Shareholdings." Journal of Finance 57, no. 6 (2002): 2741-2771.

Coles, Jeffrey L., Michael L. Lemmon and J. Felix Meschke. "Structural Models and Endogeneity in Corporate Finance: The Link between Managerial Ownership and Corporate Performance." Journal of Financial Economics 103, no. 21 (2012): 149-68.

Cottrell, Philip L., Industrial Finance, 1830-1914. London: Methuen, 1980.

Course of the Exchange (1856-70).

Crafts, Nicholas, Terence C. Mills, T. C., and Abay Mulatu. "Total Factor Productivity Growth on Britain's Railways, 1852-1912: A Reappraisal of the Evidence." Explorations in Economic History 44, no.4 (2007): 608-34.

Crafts, Nicholas, Timothy Leunig, and Abay Mulatu. "Were British Railway Companies Well Managed in the Early Twentieth Century?' Economic History Review 61, no. 4 (2008): 842-66.

Dahya, Jay, Orlin Dimitrov and John J. McConnell. "Dominant Shareholders, Corporate Boards, and Corporate Value: A Cross-Country Analysis." Journal of Financial Economics 87, no. 1 (2008): 73-100.

Davies, J. R., David Hillier and Patrick McColgan. "Ownership Structure, Managerial Behavior and Corporate Value.” Journal of Corporate Finance 11, no. 4 (2005): 645-60.

Demsetz, Harold and Kenneth Lehn. "The Structure of Corporate Ownership: Causes and Consequences." Journal of Political Economy 93, no. 6 (1985): 1155-77.

Demsetz, Harold and Belén Villalonga. "Ownership Structure and Corporate Performance." Journal of Corporate Finance 7, no. 3 (2001): 209-33. 
Directory of Directors (1880-1904).

Dybvig, Philip H. and Mitch Warachka. “Tobin's Q Does Not Measure Firm Performance: Theory, Empirics, and Alternative Measures." Working paper (2012), available at http://ssrn.com/abstract=1562444.

Edinburgh Gazette (1862-1979).

Edmans, Alex. "Blockholder Trading, Market Efficiency, and Managerial Myopia," Journal of Finance 64, no. 6 (2009): 2481-2513.

Elbaum, Bernard and William Lazonick. "The Decline of the British Economy: An Institutional Perspective." Journal of Economic History 44, no. 2 (1984): 567-83.

Fama, Eugene F. and Michael C. Jensen. "Separation of Ownership and Control." Journal of Law and Economics 24, no. 2 (1983): 301-25.

Foreman-Peck, James and Leslie Hannah. "Extreme Divorce: The Managerial Revolution in UK Companies before 1914.” Economic History Review 65, no. 4 (2012): 1217-38.

Foreman-Peck, James and Leslie Hannah. "Some Consequences of the Early TwentiethCentury British Divorce of Ownership from Control." Business History 55, no. 4 (2013): 54364.

Foreman-Peck, James and Leslie Hannah. "UK Corporate Law and Corporate Governance before 1914: A Re-interpretation.” EHES Working Papers in Economic History 72 (2015).

Freeman, Mark, Robin Pearson and James Taylor. Shareholder Democracies? Corporate Governance in Britain and Ireland before 1850. Chicago: University of Chicago Press, 2012.

Gompers, Paul A., Joy Ishii and Andrew Metrick. "Extreme Governance: An Analysis of Dual-Class Firms in the United States," Review of Financial Studies, 23, no. 3 (2010): 10511088.

Gordon, Elizabeth A., Elaine Henry, and Darius Palia. "Related Party Transactions and Corporate Governance." Advances in Financial Economics 9, no. 1 (2004): 1-27.

Grossman, Richard S. "New Indices of British Equity Prices, 1870-1913." Journal of Economic History 62, no. 1 (2002): 121-46.

Guinnane, Timothy W., Ron Harris, and Naomi R. Lamoreaux. "Contractual Freedom and the Evolution of Corporate Governance in Britain, 1862 to 1929." NBER Working Paper (2014).

Hannah, Leslie. "Takeover Bids in Britain Before 1950: An Exercise in Business PreHistory." Business History 16, no. 1 (1974): 65-77.

Hannah, Leslie. The Rise of the Corporate Economy. London: Methuen, 1976. 
Hannah, Leslie. "The Divorce of Ownership from Control from 1900: Re-calibrating Imagined Global Historical Trends.” Business History 49 (2007): 404-38.

Hannah, Leslie. "The Shareholders' 'Dog' That Did Not Bark: Contested Takeover Bids in Long-Run Comparative Perspective." In Men, Women, And Money: Perspectives on Gender, Wealth, and Investment 1850-1930, edited by David R. Green, Alasdair Owens, Josephine Maltby and Janette Rutterford, 228-47. Oxford: Oxford University Press, 2011.

Harris, Ron. Industrializing English Law: Entrepreneurship and Business Organization. Cambridge: Cambridge University Press, 2000.

Hilt, Eric. "When Did Ownership Separate from Control? Corporate Governance in the Early Nineteenth Century.” Journal of Economic History 68, no. 3 (2008), pp. 645-85.

Hilt, Eric. "Shareholder Voting Rights in Early American Corporations." Business History 55, no.4 (2013): 620-635.

Holderness, Clifford G. "The Myth of Diffuse Ownership in the United States." Review of Financial Studies 22, no. 4 (2009): 1377-408.

Investor's Monthly Manual (1880-1902).

Jefferys, J. B. Business Organisation in Great Britain 1856-1914. New York: Arno Press, 1977.

Jensen, Michael C. and William H. Meckling. "Theory of the Firm: Managerial Behavior, Agency Costs and Ownership Structure." Journal of Financial Economics 3, no. 4 (1976): 305-360.

Kennedy, William P. Industrial Structure, Capital Markets and the Origins of British Economic Decline. Cambridge: Cambridge University Press, 1987.

Kim, Kenneth A., P. Kitsabunnarat-Chatjuthamard, and John R. Nofsinger. "Large Shareholders, Board Independence, and Minority Shareholder Rights: Evidence from Europe," Journal of Corporate Finance 13, no. 5 (2007): 859-880.

Kim, E. Han and Yao Lu. "CEO Ownership, External Governance, and Risk-Taking." Journal of Financial Economics 102, no. 2 (2011): 272-92.

La Porta, Rafael, Florencio Lopez-De-Silanes, Andrei Shleifer, and Robert W. Vishny. "Law and Finance." Journal of Political Economy 106, no. 6 (1998): 1113-55.

La Porta, Rafael, Florencio Lopez-De-Silanes, and Andrei Shleifer. "Corporate Ownership Around the World." Journal of Finance 54, no. 2 (1999): 471-517.

Lipartito, Kenneth and Yumiko Morii. "Rethinking the Separation of Ownership from Management in American History." Seattle University Law Review 33, (2010): 1025-63.

London Gazette (1862-1979). 
Maury, Benjamin. "Family Ownership and Firm Performance: Empirical Evidence from Western European Corporations." Journal of Corporate Finance 12, no. 2 (2006), 321-41.

Mayer, Colin. Firm Commitment: Why the Corporation is Failing Us and How to Restore Trust In It. Oxford: Oxford University Press, 2013.

Michie, Ranald C. The London Stock Exchange. Oxford: Oxford University Press, 1999.

Mitchell, Brian R., David Chambers and N. F. R. Crafts. "How Good Was the Profitability of British Railways, 1870-1912?” Economic History Review 64, no. 4 (2011): 798-831.

McConnell, John J. and Henri Servaes. "Additional Evidence on Equity Ownership and Corporate Value.” Journal of Financial Economics 27, no. 2 (1990): 595-612.

Morck, Randall, Andrei Shleifer and Robert W. Vishny. "Management Ownership and Market Valuation: An Empirical Analysis." Journal of Financial Economics 20, no. 1 (1988): 293-315.

Musacchio, Aldo. Experiments in Financial Democracy: Corporate Governance and Financial Development in Brazil, 1882-1950. Cambridge: Cambridge University Press, 2009.

Pargendler, Mariana and Henry Hansmann. "A New View of Shareholder Voting in the Nineteenth Century: Evidence from Brazil, England and France." Business History 55, no.4 (2013): 585-600.

Peng, Winnie Qian and Wei, K.C. John and Yang, Zhishu. "Tunneling or Propping: Evidence from Connected Transactions in China," Journal of Corporate Finance 17, no. 2 (2011): 306325.

Raynes, H. E. "The Place of Ordinary Stocks and Shares in the Investment of Life Assurance Funds." Journal of the Institute of Actuaries 64, (1928): 21-50.

Register of Defunct Companies, 1979.

Rutterford, Janette, David R. Green, Josephine Maltby, and Alastair Owens. "Who Comprised the Nation of Shareholders? Gender and Investment in Great Britain, c.18701935." Economic History Review 64 no. 1 (2011): 157-87.

Shleifer, Andrei and Robert W. Vishny. "Large Shareholders and Corporate Control." Journal of Political Economy 94, no. 3 (1986): 461-88.

Shleifer, Andrei and Robert W. Vishny. "A Survey of Corporate Governance," Journal of Finance 52, no. 2 (1997): 737-83.

Stock Exchange Official Intelligence (1885-1902).

Stock Exchange Yearbook (1880-1902).

Supple, Barry. The Royal Exchange Assurance: A History of British Insurance 1720-1970. Cambridge: Cambridge University Press, 1970. 
Sykes, Joseph. The Amalgamation Movement in English Banking, 1825-1924. London: P.S. King \& Son, 1926.

Taylor, James. Creating Capitalism: Joint-Stock Enterprise in British Politics and Culture 1800-1870. London: Royal Historical Society, 2006.

Taylor, James. Boardroom Scandal: the Criminalization of Company Fraud in NineteenthCentury Britain. Oxford University Press, 2013.

Thomas, W. A. The Provincial Stock Exchanges. London: Frank Cass: London, 1973.

Turner, John D., Qing Ye and Wenwen Zhan. "Why Do Firms Pay Dividends?: Evidence from an Early and Unregulated Capital Market." Review of Finance 17, (2013): 1787-1826.

Wilson, John F. British Business History, 1720-1994. Manchester: Manchester University Press, 1995. 
TABLE 1

SUMMARY STATISTICS

\begin{tabular}{|c|c|c|c|c|c|c|c|c|c|c|c|c|}
\hline & \multicolumn{6}{|c|}{ Performance Data } & \multicolumn{6}{|c|}{$\begin{array}{l}\text { Final Status Data } \\
\end{array}$} \\
\hline & $\mathrm{N}$ & Mean & $1^{\text {st }}$ percentile & Median & $99^{\text {th }}$ percentile & St. Dev & $\mathrm{N}$ & Mean & $1^{\text {st }}$ percentile & Median & $99^{\text {th }}$ percentile & St. Dev \\
\hline \multicolumn{13}{|l|}{ Voting Concentration } \\
\hline VoteLargest5 (\%) & 245 & 21.44 & 1.21 & 17.28 & 89.40 & 16.70 & 344 & 24.73 & 1.06 & 18.36 & 98.67 & 20.81 \\
\hline VoteHHI (\%) & 245 & 3.08 & 0.14 & 1.36 & 35.00 & 5.89 & 344 & 4.19 & 0.13 & 1.52 & 54.40 & 8.17 \\
\hline VoteDir (\%) & 245 & 11.53 & 0.00 & 6.99 & 69.04 & 12.00 & 344 & 13.82 & 0.55 & 8.26 & 85.31 & 16.12 \\
\hline VoteInsiders (\%) & 245 & 14.38 & 1.17 & 9.06 & 82.89 & 14.73 & 344 & 18.85 & 0.88 & 10.45 & 98.00 & 20.97 \\
\hline ActiveBlock (\%) & 245 & 3.76 & 0.00 & 0.00 & 57.31 & 10.50 & 344 & 5.43 & 0.00 & 0.00 & 84.11 & 15.44 \\
\hline PassiveBlock (\%) & 245 & 2.85 & 0.00 & 0.00 & 57.72 & 9.62 & 344 & 4.69 & 0.00 & 0.00 & 63.28 & 11.83 \\
\hline DirOnlyVote (\%) & 245 & 7.78 & 0.00 & 5.91 & 25.33 & 5.72 & 344 & 8.40 & 0.00 & 6.67 & 30.79 & 6.55 \\
\hline ActiveCEOBlock (\%) & 242 & 1.45 & 0.00 & 0.00 & 39.22 & 5.77 & & & & & & \\
\hline ActiveNotCEOBlock (\%) & 242 & 2.02 & 0.00 & 0.00 & 49.71 & 7.45 & & & & & & \\
\hline \multicolumn{13}{|l|}{ Number of Directors } \\
\hline NumDir & 252 & 6.02 & 3.00 & 6.00 & 23.00 & 2.75 & 344 & 6.24 & 3.00 & 6.00 & 19.00 & 2.50 \\
\hline DirOnlyNum & 245 & 5.84 & 2.00 & 5.00 & 23.00 & 2.88 & 344 & 5.97 & 1.00 & 6.00 & 19.00 & 2.69 \\
\hline \multirow{2}{*}{\multicolumn{13}{|c|}{$\begin{array}{l}\text { PropDirblock (\%) } \\
\text { Performance Variables }\end{array}$}} \\
\hline & & & & & & & & & & & & \\
\hline ROA (\%) & 252 & 4.97 & -2.54 & 3.74 & 21.68 & 4.66 & & & & & & \\
\hline $\mathrm{Q}$ & 217 & 0.94 & 0.28 & 0.91 & 2.49 & 0.34 & & & & & & \\
\hline Merged & & & & & & & 344 & 0.41 & 0.00 & 0.00 & 1.00 & 0.49 \\
\hline CourtWoundUp & & & & & & & 344 & 0.05 & 0.00 & 0.00 & 1.00 & 0.22 \\
\hline Removed & & & & & & & 344 & 0.15 & 0.00 & 0.00 & 1.00 & 0.36 \\
\hline VolWoundUp & & & & & & & 344 & 0.24 & 0.00 & 0.00 & 1.00 & 0.42 \\
\hline Reconstructed & & & & & & & 344 & 0.16 & 0.00 & 0.00 & 1.00 & 0.36 \\
\hline \multicolumn{13}{|l|}{ Control Variables } \\
\hline OwnDate & 252 & 1892 & 1881 & 1890 & 1901 & 6.87 & 344 & 1883 & 1862 & 1883 & 1901 & 10.6 \\
\hline EstDate & 249 & 1871 & 1824 & 1874 & 1897 & 16.91 & 340 & 1871 & 1825 & 1872 & 1897 & 16.1 \\
\hline Size (£000s) & 251 & 256.70 & 16.96 & 150.00 & $1,806.98$ & 301.68 & 342 & 216.56 & 3.16 & 133.10 & $1,362.45$ & 243.42 \\
\hline DirectorQual & 251 & 0.37 & 0.00 & 0.24 & 1.76 & 0.39 & 342 & 0.43 & 0.00 & 0.27 & 2.54 & 0.51 \\
\hline HeadLondon & 250 & 0.48 & 0.00 & 0.00 & 1.00 & 0.50 & 298 & 0.54 & 0.00 & 1.00 & 1.00 & 0.50 \\
\hline Scottish & 252 & 0.21 & 0.00 & 0.00 & 1.00 & 0.41 & 344 & 0.13 & 0.00 & 0.00 & 1.00 & 0.33 \\
\hline LTDebt (\%) & 252 & 13.52 & 0.00 & 0.04 & 73.31 & 18.94 & & & & & & \\
\hline ActiveCashWedge (\%) & 224 & -0.29 & -23.61 & 0.00 & 13.16 & 2.39 & & & & & & \\
\hline VoteNonLinear & 245 & 0.36 & 0.00 & 0.00 & 1.00 & 0.48 & & & & & & \\
\hline Uncalled & 252 & 6.58 & 0.00 & 0.00 & 97.50 & 15.18 & & & & & & \\
\hline
\end{tabular}


TABLE 2

DIRECTORS AND LARGE BLOCKHOLDERS BY INDUSTRY FOR THE POST-1880 PERFORMANCE SAMPLE

\begin{tabular}{|c|c|c|c|c|c|c|c|c|c|c|c|c|c|c|c|}
\hline & \multirow[b]{2}{*}{$\mathrm{N}$} & \multicolumn{6}{|c|}{ Mean number of individuals who were: } & \multicolumn{6}{|c|}{ Mean \% of votes controlled by: } & \multicolumn{2}{|c|}{ Mean propensity of } \\
\hline & & 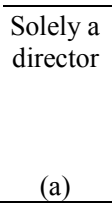 & $\begin{array}{l}\text { Passive } \\
\text { Block } \\
\text { holder } \\
\\
\text { (b) } \\
\end{array}$ & $\begin{array}{c}\text { Active } \\
\text { Block } \\
\text { holder } \\
\text { (c) }\end{array}$ & $(a+c)$ & $\begin{array}{l}\text { Large } \\
\text { block- } \\
\text { holders } \\
(\mathrm{b}+\mathrm{c}) \\
\end{array}$ & $\begin{array}{l}\text { Insiders } \\
(\mathrm{a}+\mathrm{b}+\mathrm{c}) \\
\end{array}$ & $\begin{array}{l}\text { Solely a } \\
\text { director }\end{array}$ & $\begin{array}{l}\text { Passive } \\
\text { Block } \\
\text { holder } \\
\\
\text { (e) } \\
\end{array}$ & $\begin{array}{l}\text { Active } \\
\text { Block } \\
\text { holder } \\
\text { (f) }\end{array}$ & $(\mathrm{d}+\mathrm{f})$ & $\begin{array}{l}\text { Large } \\
\text { block- } \\
\text { holders }\end{array}$ & $\begin{array}{l}\text { Insiders } \\
(\mathrm{d}+\mathrm{e}+\mathrm{f}) \\
\end{array}$ & $\begin{array}{c}\text { Director to } \\
\text { be a large } \\
\text { blockholder (\%) } \\
\mathrm{c} /(\mathrm{a}+\mathrm{c})\end{array}$ & $\begin{array}{c}\text { Large } \\
\text { blockholder } \\
\text { to be a } \\
\text { director (\%) } \\
\mathrm{c} /(\mathrm{b}+\mathrm{c}) \\
\end{array}$ \\
\hline Banks & 38 & 7.0 & 0.0 & 0.0 & 7.1 & 0.0 & 7.1 & 6.3 & 0.0 & 0.4 & 6.7 & 0.4 & 6.7 & 0.4 & 100.0 \\
\hline Breweries & 3 & 3.0 & 0.0 & 1.3 & 4.3 & 1.3 & 4.3 & 8.1 & 0.0 & 29.9 & 38.0 & 29.9 & 38.0 & 30.8 & 100.0 \\
\hline Gas, Light \& Coke & 11 & 5.5 & 0.5 & 0.2 & 5.7 & 0.7 & 6.3 & 4.5 & 13.6 & 4.3 & 8.8 & 17.9 & 22.4 & 3.2 & 25.0 \\
\hline Industrial \& Commercial & 63 & 4.7 & 0.3 & 0.5 & 5.2 & 0.7 & 5.5 & 8.3 & 5.3 & 8.0 & 16.3 & 13.3 & 21.6 & 8.8 & 64.4 \\
\hline Insurance & 15 & 12.7 & 0.0 & 0.1 & 12.9 & 0.1 & 12.9 & 8.5 & 0.0 & 1.8 & 10.2 & 1.8 & 10.2 & 1.0 & 100.0 \\
\hline Iron, Coal \& Steel & 30 & 4.9 & 0.1 & 0.3 & 5.2 & 0.5 & 5.3 & 10.2 & 2.0 & 7.9 & 18.1 & 9.9 & 20.1 & 6.4 & 71.4 \\
\hline Mines & 10 & 5.0 & 0.1 & 0.1 & 5.1 & 0.2 & 5.2 & 6.1 & 1.5 & 2.2 & 8.3 & 3.7 & 9.9 & 2.0 & 50.0 \\
\hline Mortgage \& Finance & 34 & 5.6 & 0.1 & 0.0 & 5.6 & 0.1 & 5.7 & 6.8 & 2.2 & 0.4 & 7.2 & 2.6 & 9.4 & 0.5 & 33.3 \\
\hline Steamships & 14 & 6.1 & 0.1 & 0.1 & 6.1 & 0.2 & 6.3 & 11.2 & 1.6 & 0.8 & 12.0 & 2.4 & 13.6 & 1.2 & 33.3 \\
\hline Telegraph & 7 & 5.9 & 0.4 & 0.0 & 5.9 & 0.4 & 6.3 & 5.0 & 12.1 & 0.0 & 5.0 & 12.1 & 17.0 & 0.0 & 0.0 \\
\hline Tramways & 13 & 4.7 & 0.0 & 0.0 & 4.7 & 0.0 & 4.7 & 4.2 & 0.0 & 0.0 & 4.2 & 0.0 & 4.2 & 0.0 & - \\
\hline Wagon & 7 & 5.0 & 0.0 & 0.1 & 5.1 & 0.1 & 5.1 & 14.8 & 0.0 & 2.2 & 17.0 & 2.2 & 17.0 & 2.8 & 100.0 \\
\hline Total & 245 & 5.9 & 0.1 & 0.2 & 6.1 & 0.4 & 6.2 & 7.8 & 3.0 & 4.0 & 11.8 & 7.0 & 14.8 & 3.5 & 60.5 \\
\hline
\end{tabular}

Notes: The propensity for a director to be a large blockholder is calculated as (ActiveBlockholder)/(Solely Director + ActiveBlockholder) and the propensity for a large blockholder to be a director calculated as (ActiveBlockholder)/(Passive Blockholder + Active Blockholder). 
TABLE 3

PAIRWISE CORRELATIONS BETWEEN PERFORMANCE AND OWNERSHIP CONCENTRATION MEASURES

\begin{tabular}{|c|c|c|c|c|c|c|c|c|c|c|c|}
\hline & ROA & Tobin's Q & VoteLargest5 (\%) & VoteHHI (\%) & VoteInsiders (\%) & VoteDir (\%) & ActiveBlock (\%) & PassiveBlock (\%) & DirOnlyVote (\%) & NumDir & DirOnlyNum \\
\hline ROA & 1.00 & & & & & & & & & & \\
\hline Tobin’s Q & $0.49^{* * *}$ & 1.00 & & & & & & & & & \\
\hline VoteLargest5 (\%) & 0.06 & -0.05 & 1.00 & & & & & & & & \\
\hline VoteHHI (\%) & 0.03 & -0.01 & $0.86^{* * *}$ & 1.00 & & & & & & & \\
\hline VoteInsiders (\%) & 0.10 & 0.04 & $0.93 * * *$ & $0.83 * * *$ & 1.00 & & & & & & \\
\hline VoteDir (\%) & $0.14 * *$ & 0.06 & $0.69 * * *$ & $0.49 * * *$ & $0.76^{* * *}$ & 1.00 & & & & & \\
\hline ActiveBlock (\%) & $0.16^{* *}$ & 0.04 & $0.68^{* * *}$ & $0.59^{* * *}$ & $0.70^{* * *}$ & $0.88^{* * *}$ & 1.00 & & & & \\
\hline PassiveBlock (\%) & -0.02 & 0.00 & $0.57 * * *$ & $0.66^{* * *}$ & $0.58 * * *$ & -0.09 & -0.03 & 1.00 & & & \\
\hline DirOnlyVote (\%) & 0.01 & 0.05 & $0.20 * * *$ & -0.04 & $0.31 * * *$ & $0.48^{* * *}$ & 0.01 & $-0.13 * *$ & 1.00 & & \\
\hline NumDir & 0.02 & $0.26^{* * *}$ & $-0.25 * * *$ & $-0.14 * *$ & $-0.12 *$ & -0.04 & -0.09 & $-0.14 * *$ & 0.09 & 1.00 & \\
\hline DirOnlyNum & -0.01 & $0.25^{* * *}$ & $-0.34 * * *$ & $-0.21 * * *$ & $-0.23 * * *$ & $-0.18^{* * * *}$ & $-0.25 * * *$ & $-0.13 * *$ & 0.08 & $0.98^{* * *}$ & 1.00 \\
\hline
\end{tabular}

Notes: ${ }^{* * *} \mathrm{p}<0.01,{ }^{* *} \mathrm{p}<0.05,{ }^{*} \mathrm{p}<0.1$. ROA and $\mathrm{Q}$ are industry adjusted and outliers have been winsorized at the $1 \%$ and $99 \%$ levels. 
TABLE 4

DETERMINANTS OF RETURN ON ASSETS AND TOBIN'S Q

\begin{tabular}{|c|c|c|c|c|c|c|c|c|}
\hline & (1) & (2) & (3) & (4) & $(5)$ & (6) & (7) & $(8)$ \\
\hline \multicolumn{9}{|l|}{ PANEL A } \\
\hline VoteLargest5 & $\begin{array}{c}0.002 \\
(0.003)\end{array}$ & & & & $\begin{array}{c}0.002 \\
(0.004)\end{array}$ & & & \\
\hline VoteHHI & & $\begin{array}{c}0.002 \\
(0.002)\end{array}$ & & & & $\begin{array}{c}0.002 \\
(0.003)\end{array}$ & & \\
\hline VoteInsiders & & & $\begin{array}{l}0.004 * \\
(0.002)\end{array}$ & & & & $\begin{array}{c}0.004 \\
(0.003)\end{array}$ & \\
\hline VoteDir & & & & $\begin{array}{c}0.007 * * * \\
(0.003)\end{array}$ & & & & $\begin{array}{c}0.007 * * \\
(0.003)\end{array}$ \\
\hline NumDir & & & & & $\begin{array}{c}0.000 \\
(0.001)\end{array}$ & $\begin{array}{c}0.000 \\
(0.001)\end{array}$ & $\begin{array}{c}0.000 \\
(0.001)\end{array}$ & $\begin{array}{l}-0.000 \\
(0.001)\end{array}$ \\
\hline EstDate & & & & & $\begin{array}{c}0.000 \\
(0.000)\end{array}$ & $\begin{array}{c}0.000 \\
(0.000)\end{array}$ & $\begin{array}{c}0.000 \\
(0.000)\end{array}$ & $\begin{array}{c}0.000 \\
(0.000)\end{array}$ \\
\hline Size & & & & & $\begin{array}{c}0.002 \\
(0.004)\end{array}$ & $\begin{array}{c}0.002 \\
(0.004)\end{array}$ & $\begin{array}{c}0.001 \\
(0.004)\end{array}$ & $\begin{array}{c}0.001 \\
(0.004)\end{array}$ \\
\hline DirectorQual & & & & & $\begin{array}{c}0.006 \\
(0.008)\end{array}$ & $\begin{array}{c}0.006 \\
(0.008)\end{array}$ & $\begin{array}{c}0.004 \\
(0.008)\end{array}$ & $\begin{array}{c}0.000 \\
(0.008)\end{array}$ \\
\hline HeadLondon & & & & & $\begin{array}{c}0.005 \\
(0.006)\end{array}$ & $\begin{array}{c}0.005 \\
(0.006)\end{array}$ & $\begin{array}{c}0.006 \\
(0.006)\end{array}$ & $\begin{array}{c}0.007 \\
(0.006)\end{array}$ \\
\hline Scottish & & & & & $\begin{array}{c}0.016^{* *} \\
(0.008)\end{array}$ & $\begin{array}{c}0.016 * * \\
(0.008)\end{array}$ & $\begin{array}{c}0.016 * * \\
(0.008)\end{array}$ & $\begin{array}{c}0.017 * * \\
(0.008)\end{array}$ \\
\hline LTDebt & & & & & $\begin{array}{c}-0.054 * * * \\
(0.011)\end{array}$ & $\begin{array}{c}-0.054 * * * \\
(0.011)\end{array}$ & $\begin{array}{c}-0.054 * * * \\
(0.011)\end{array}$ & $\begin{array}{c}-0.054 * * * \\
(0.011)\end{array}$ \\
\hline Constant & $\begin{array}{c}0.024 \\
(0.022)\end{array}$ & $\begin{array}{c}0.030 \\
(0.023)\end{array}$ & $\begin{array}{c}0.029 \\
(0.021)\end{array}$ & $\begin{array}{c}0.034 \\
(0.021)\end{array}$ & $\begin{array}{l}-0.237 \\
(0.394)\end{array}$ & $\begin{array}{l}-0.206 \\
(0.396)\end{array}$ & $\begin{array}{l}-0.178 \\
(0.363)\end{array}$ & $\begin{array}{l}-0.095 \\
(0.353)\end{array}$ \\
\hline Year Dummies & YES & YES & YES & YES & YES & YES & YES & YES \\
\hline Observations & 245 & 245 & 245 & 245 & 241 & 241 & 241 & 241 \\
\hline R-squared & 0.097 & 0.099 & 0.105 & 0.120 & 0.173 & 0.175 & 0.178 & 0.194 \\
\hline \multicolumn{9}{|l|}{ PANEL B } \\
\hline VoteLargest5 & $\begin{array}{c}-0.047 * \\
(0.028)\end{array}$ & & & & $\begin{array}{c}-0.035 \\
(0.024)\end{array}$ & & & \\
\hline VoteHHI & & $\begin{array}{c}-0.027 \\
(0.021)\end{array}$ & & & & $\begin{array}{c}-0.023 \\
(0.018)\end{array}$ & & \\
\hline VoteInsiders & & & $\begin{array}{c}0.017 \\
(0.020)\end{array}$ & & & & $\begin{array}{c}-0.009 \\
(0.018)\end{array}$ & \\
\hline VoteDir & & & & $\begin{array}{c}0.032 \\
(0.022)\end{array}$ & & & & $\begin{array}{c}-0.022 \\
(0.020)\end{array}$ \\
\hline NumDir & & & & & $\begin{array}{c}0.029 * * * \\
(0.010)\end{array}$ & $\begin{array}{c}0.030 * * * \\
(0.010)\end{array}$ & $\begin{array}{c}0.032 * * * \\
(0.010)\end{array}$ & $\begin{array}{c}0.033 * * * \\
(0.010)\end{array}$ \\
\hline ROA & & & & & $\begin{array}{c}4.003 * * * \\
(0.678)\end{array}$ & $\begin{array}{c}4.010 * * * \\
(0.681)\end{array}$ & $\begin{array}{c}3.974 * * * \\
(0.696)\end{array}$ & $\begin{array}{c}4.038 * * * \\
(0.698)\end{array}$ \\
\hline EstDate & & & & & $\begin{array}{l}-0.001 \\
(0.001)\end{array}$ & $\begin{array}{l}-0.001 \\
(0.001)\end{array}$ & $\begin{array}{c}-0.001 \\
(0.001)\end{array}$ & $\begin{array}{c}-0.001 \\
(0.001)\end{array}$ \\
\hline Size & & & & & $\begin{array}{l}-0.033 \\
(0.024)\end{array}$ & $\begin{array}{l}-0.034 \\
(0.024)\end{array}$ & $\begin{array}{l}-0.033 \\
(0.024)\end{array}$ & $\begin{array}{l}-0.032 \\
(0.024)\end{array}$ \\
\hline DirectorQual & & & & & $\begin{array}{c}0.085 \\
(0.065)\end{array}$ & $\begin{array}{c}0.082 \\
(0.065)\end{array}$ & $\begin{array}{c}0.074 \\
(0.065)\end{array}$ & $\begin{array}{c}0.086 \\
(0.067)\end{array}$ \\
\hline HeadLondon & & & & & $\begin{array}{c}-0.006 \\
(0.046)\end{array}$ & $\begin{array}{c}-0.006 \\
(0.046)\end{array}$ & $\begin{array}{c}-0.008 \\
(0.047)\end{array}$ & $\begin{array}{c}-0.012 \\
(0.047)\end{array}$ \\
\hline Scottish & & & & & $\begin{array}{c}0.015 \\
(0.060)\end{array}$ & $\begin{array}{c}0.018 \\
(0.060)\end{array}$ & $\begin{array}{c}0.024 \\
(0.060)\end{array}$ & $\begin{array}{c}0.022 \\
(0.060)\end{array}$ \\
\hline LTDebt & & & & & $\begin{array}{l}0.232 * * \\
(0.091)\end{array}$ & $\begin{array}{c}0.236 * * \\
(0.091)\end{array}$ & $\begin{array}{c}0.238 * * * \\
(0.090)\end{array}$ & $\begin{array}{c}0.243 * * * \\
(0.090)\end{array}$ \\
\hline Constant & $\begin{array}{c}0.147 \\
(0.322)\end{array}$ & $\begin{array}{c}0.115 \\
(0.335)\end{array}$ & $\begin{array}{c}0.261 \\
(0.320)\end{array}$ & $\begin{array}{c}0.293 \\
(0.321)\end{array}$ & $\begin{array}{c}1.600 \\
(2.802)\end{array}$ & $\begin{array}{c}2.060 \\
(2.708)\end{array}$ & $\begin{array}{c}2.934 \\
(2.530)\end{array}$ & $\begin{array}{c}2.642 \\
(2.464)\end{array}$ \\
\hline Year Dummies & YES & YES & YES & YES & YES & YES & YES & YES \\
\hline Observations & 212 & 212 & 212 & 212 & 211 & 211 & 211 & 211 \\
\hline R-squared & 0.107 & 0.099 & 0.095 & 0.100 & 0.399 & 0.398 & 0.395 & 0.397 \\
\hline
\end{tabular}

Notes: In Panel A industry-adjusted ROA is the dependent variable and in Panel B industry-adjusted Tobin's Q is the dependent variable. $* * * \mathrm{p}<0.01, * * \mathrm{p}<0.05, * \mathrm{p}<0.1$. Robust standard errors are in parentheses 
TABLE 5

DIFFERENCES IN PERFORMANCE WITH ALTERNATIVE CONCENTRATION MEASURES

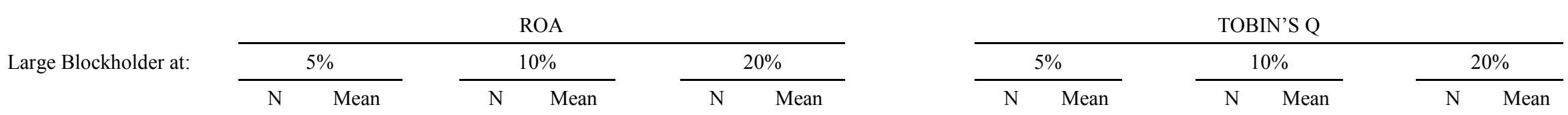

Companies with:

\begin{tabular}{|c|c|c|c|c|c|c|c|c|c|c|c|c|c|c|c|c|c|c|}
\hline \multicolumn{19}{|c|}{ Panel A: Active Blockholders } \\
\hline $\begin{array}{l}\text { At least one Active } \\
\text { Blockholder }\end{array}$ & 73 & $6.5 \%$ & & 37 & $7.6 \%$ & & 13 & $8.4 \%$ & & 59 & 0.94 & & 30 & 0.93 & & 8 & 0.90 & \\
\hline No Active Blockholders & 172 & $4.3 \%$ & & 208 & $4.5 \%$ & & 232 & $4.8 \%$ & & 153 & 0.95 & & 182 & 0.95 & & 204 & 0.95 & \\
\hline Difference in means & & $2.3 \%$ & $* * *$ & & $3.1 \%$ & $* * *$ & & $3.6 \%$ & $* * *$ & & -0.01 & & & -0.01 & & & -0.04 & \\
\hline \multicolumn{19}{|c|}{ Panel B: Passive Blockholders } \\
\hline $\begin{array}{l}\text { At least one Passive } \\
\text { Blockholder }\end{array}$ & 93 & $5.6 \%$ & & 28 & $5.5 \%$ & & 9 & $4.4 \%$ & & 76 & 0.90 & & 22 & 0.88 & & 7 & 0.93 & \\
\hline No Passive Blockholders & 152 & $4.5 \%$ & & 217 & $4.9 \%$ & & 236 & $5.0 \%$ & & 136 & 0.97 & & 190 & 0.95 & & 205 & 0.94 & \\
\hline Difference in means & & $1.1 \%$ & $*$ & & $0.6 \%$ & & & $-0.6 \%$ & & & -0.07 & & & -0.07 & & & -0.01 & \\
\hline \multicolumn{19}{|c|}{ Panel C: Solely Directors } \\
\hline $\begin{array}{l}\text { Above Median number of } \\
\text { individuals who were } \\
\text { Solely Directors }\end{array}$ & 108 & $4.8 \%$ & & 118 & $4.9 \%$ & & 75 & $4.8 \%$ & & 101 & 1.02 & & 111 & 1.01 & & 70 & 1.07 & \\
\hline $\begin{array}{l}\text { Below Median number of } \\
\text { individuals who were } \\
\text { Solely Directors }\end{array}$ & 137 & $5.1 \%$ & & 127 & $5.0 \%$ & & 170 & $5.0 \%$ & & 111 & 0.87 & & 101 & 0.87 & & 142 & 0.88 & \\
\hline Difference in means & & $-0.3 \%$ & & & $-0.2 \%$ & & & $-0.3 \%$ & & & 0.15 & $* * *$ & & 0.14 & $* * *$ & & 0.19 & $* * *$ \\
\hline
\end{tabular}


TABLE 6

DETERMINANTS OF RETURN ON ASSETS, DISTINGUISHING THE INTERACTION BETWEEN LARGE BLOCKHOLDERS AND DIRECTORS

\begin{tabular}{|c|c|c|c|c|c|c|c|c|}
\hline & (1) & $(2)$ & (3) & (4) & (5) & (6) & (7) & $(8)$ \\
\hline ActiveBlock & $\begin{array}{c}0.060 * * \\
(0.027)\end{array}$ & & & & $\begin{array}{c}0.302 * * * \\
(0.090)\end{array}$ & $\begin{array}{c}0.285 * * * \\
(0.095)\end{array}$ & & $\begin{array}{c}0.262 * * * \\
(0.095)\end{array}$ \\
\hline PassiveBlock & & $\begin{array}{l}-0.021 \\
(0.028)\end{array}$ & & & $\begin{array}{l}-0.014 \\
(0.032)\end{array}$ & $\begin{array}{l}-0.020 \\
(0.031)\end{array}$ & $\begin{array}{l}-0.023 \\
(0.032)\end{array}$ & $\begin{array}{l}-0.020 \\
(0.031)\end{array}$ \\
\hline DirOnlyVote & & & $\begin{array}{c}0.015 \\
(0.042)\end{array}$ & & $\begin{array}{l}-0.015 \\
(0.046)\end{array}$ & $\begin{array}{c}0.007 \\
(0.048)\end{array}$ & $\begin{array}{c}0.018 \\
(0.050)\end{array}$ & $\begin{array}{c}0.013 \\
(0.051)\end{array}$ \\
\hline DirOnlyNum & & & & $\begin{array}{l}-0.000 \\
(0.001)\end{array}$ & $\begin{array}{c}0.001 \\
(0.001)\end{array}$ & $\begin{array}{l}-0.000 \\
(0.001)\end{array}$ & $\begin{array}{l}-0.000 \\
(0.001)\end{array}$ & \\
\hline ActiveCEOBlock & & & & & & & $\begin{array}{l}0.321^{*} \\
(0.171)\end{array}$ & \\
\hline ActiveNotCEOBlock & & & & & & & $\begin{array}{c}0.278 * * \\
(0.139)\end{array}$ & \\
\hline ActiveCEOBlockSq & & & & & & & $\begin{array}{l}-0.894^{*} \\
(0.497)\end{array}$ & \\
\hline ActiveNotCEOBlockSq & & & & & & & $\begin{array}{l}-0.510^{*} \\
(0.284)\end{array}$ & \\
\hline NumDir & & & & & & & & $\begin{array}{l}-0.000 \\
(0.001)\end{array}$ \\
\hline PropDirectorsBlock & & & & & & & & $\begin{array}{c}0.021 \\
(0.034)\end{array}$ \\
\hline ActiveBlockSq & & & & & $\begin{array}{c}-0.558 * * * \\
(0.179)\end{array}$ & $\begin{array}{c}-0.513 * * * \\
(0.180)\end{array}$ & & $\begin{array}{c}-0.501 * * * \\
(0.173)\end{array}$ \\
\hline ActiveCashWedge & & & & & $\begin{array}{l}-0.175 \\
(0.122)\end{array}$ & $\begin{array}{l}-0.160 \\
(0.112)\end{array}$ & $\begin{array}{l}-0.132 \\
(0.105)\end{array}$ & $\begin{array}{l}-0.169 \\
(0.113)\end{array}$ \\
\hline DirFamily & & & & & $\begin{array}{l}-0.008 \\
(0.008)\end{array}$ & $\begin{array}{l}-0.009 \\
(0.008)\end{array}$ & $\begin{array}{l}-0.012 \\
(0.008)\end{array}$ & $\begin{array}{l}-0.011 \\
(0.008)\end{array}$ \\
\hline EstDate & & & & & & $\begin{array}{c}0.000 \\
(0.000)\end{array}$ & $\begin{array}{c}0.000 \\
(0.000)\end{array}$ & $\begin{array}{c}0.000 \\
(0.000)\end{array}$ \\
\hline Size & & & & & & $\begin{array}{c}0.000 \\
(0.004)\end{array}$ & $\begin{array}{c}0.001 \\
(0.004)\end{array}$ & $\begin{array}{c}0.000 \\
(0.004)\end{array}$ \\
\hline DirectorQual & & & & & & $\begin{array}{l}-0.005 \\
(0.009)\end{array}$ & $\begin{array}{l}-0.007 \\
(0.009)\end{array}$ & $\begin{array}{l}-0.006 \\
(0.009)\end{array}$ \\
\hline HeadLondon & & & & & & $\begin{array}{c}0.007 \\
(0.006)\end{array}$ & $\begin{array}{c}0.007 \\
(0.007)\end{array}$ & $\begin{array}{c}0.007 \\
(0.007)\end{array}$ \\
\hline Scottish & & & & & & $\begin{array}{c}0.017 * * \\
(0.008)\end{array}$ & $\begin{array}{c}0.017 * * \\
(0.008)\end{array}$ & $\begin{array}{c}0.017 * * \\
(0.008)\end{array}$ \\
\hline LTDebt & & & & & & $\begin{array}{c}-0.052 * * * \\
(0.012)\end{array}$ & $\begin{array}{c}-0.053 * * * \\
(0.012)\end{array}$ & $\begin{array}{c}-0.053 * * * \\
(0.012)\end{array}$ \\
\hline Constant & $\begin{array}{c}0.018 \\
(0.020)\end{array}$ & $\begin{array}{c}0.020 \\
(0.021)\end{array}$ & $\begin{array}{c}0.018 \\
(0.023)\end{array}$ & $\begin{array}{c}0.021 \\
(0.022)\end{array}$ & $\begin{array}{c}0.008 \\
(0.020)\end{array}$ & $\begin{array}{l}-0.138 \\
(0.396)\end{array}$ & $\begin{array}{l}-0.133 \\
(0.413)\end{array}$ & $\begin{array}{l}-0.141 \\
(0.398)\end{array}$ \\
\hline Year Dummies & YES & YES & YES & YES & YES & YES & YES & YES \\
\hline $\begin{array}{l}\text { Observations } \\
\text { R-squared }\end{array}$ & $\begin{array}{c}245 \\
0.119\end{array}$ & $\begin{array}{c}245 \\
0.097\end{array}$ & $\begin{array}{c}245 \\
0.095\end{array}$ & $\begin{array}{c}245 \\
0.095\end{array}$ & $\begin{array}{c}224 \\
0.168\end{array}$ & $\begin{array}{c}221 \\
0.239\end{array}$ & $\begin{array}{c}219 \\
0.234\end{array}$ & $\begin{array}{c}221 \\
0.239\end{array}$ \\
\hline
\end{tabular}

Notes: *** $\mathrm{p}<0.01, * * \mathrm{p}<0.05,{ }^{*} \mathrm{p}<0.1$. Robust standard errors are in parentheses. Dependent variable is industry-adjusted ROA. All outliers have been winsorized at the $1 \%$ and $99 \%$ levels. 
TABLE 7

DETERMINANTS OF TOBIN'S Q, DISTINGUISHING THE INTERACTION BETWEEN LARGE BLOCKHOLDERS AND DIRECTORS

\begin{tabular}{|c|c|c|c|c|c|c|c|c|}
\hline & $(1)$ & $(2)$ & (3) & $(4)$ & $(5)$ & $(6)$ & $(7)$ & $(8)$ \\
\hline ActiveBlock & $\begin{array}{c}0.183 \\
(0.273)\end{array}$ & & & & $\begin{array}{c}0.794 \\
(1.411)\end{array}$ & $\begin{array}{c}0.190 \\
(1.401)\end{array}$ & & $\begin{array}{c}-0.707 \\
(1.899)\end{array}$ \\
\hline PassiveBlock & & $\begin{array}{c}-0.198 \\
(0.201)\end{array}$ & & & $\begin{array}{c}-0.084 \\
(0.181)\end{array}$ & $\begin{array}{c}0.041 \\
(0.171)\end{array}$ & $\begin{array}{c}0.041 \\
(0.171)\end{array}$ & $\begin{array}{c}0.042 \\
(0.175)\end{array}$ \\
\hline DirOnlyVote & & & $\begin{array}{c}0.126 \\
(0.352)\end{array}$ & & $\begin{array}{c}-0.312 \\
(0.341)\end{array}$ & $\begin{array}{c}-0.390 \\
(0.338)\end{array}$ & $\begin{array}{c}-0.392 \\
(0.328)\end{array}$ & $\begin{array}{c}-0.309 \\
(0.346)\end{array}$ \\
\hline DirOnlyNum & & & & $\begin{array}{c}0.025 * * \\
(0.012)\end{array}$ & $\begin{array}{c}0.027 * * * \\
(0.009)\end{array}$ & $\begin{array}{c}0.032 * * * \\
(0.011)\end{array}$ & $\begin{array}{c}0.032 * * * \\
(0.011)\end{array}$ & \\
\hline ActiveCEOBlock & & & & & & & $\begin{array}{c}0.246 \\
(2.614)\end{array}$ & \\
\hline ActiveNotCEOBlock & & & & & & & $\begin{array}{c}0.410 \\
(1.392)\end{array}$ & \\
\hline ActiveCEOBlockSq & & & & & & & $\begin{array}{l}-4.590 \\
(5.333)\end{array}$ & \\
\hline ActiveNotCEOBlockSq & & & & & & & $\begin{array}{l}-4.480 \\
(3.385)\end{array}$ & \\
\hline NumDir & & & & & & & & $\begin{array}{c}0.032 * * * \\
(0.011)\end{array}$ \\
\hline PropDirectorsBlock & & & & & & & & $\begin{array}{c}0.373 \\
(0.506)\end{array}$ \\
\hline ActiveBlockSq & & & & & $\begin{array}{c}-2.256 \\
(3.078)\end{array}$ & $\begin{array}{c}-0.637 \\
(3.009)\end{array}$ & $\begin{array}{c}2.838 \\
(3.641)\end{array}$ & $\begin{array}{c}0.515 \\
(3.616)\end{array}$ \\
\hline ActiveCashWedge & & & & & $\begin{array}{c}-0.875 \\
(1.763)\end{array}$ & $\begin{array}{c}-0.536 \\
(1.509)\end{array}$ & $\begin{array}{l}-1.015 \\
(1.664)\end{array}$ & $\begin{array}{c}-0.659 \\
(1.421)\end{array}$ \\
\hline DirFamily & & & & & $\begin{array}{c}-0.074 \\
(0.103)\end{array}$ & $\begin{array}{c}-0.048 \\
(0.099)\end{array}$ & $\begin{array}{l}-0.061 \\
(0.099)\end{array}$ & $\begin{array}{c}-0.074 \\
(0.102)\end{array}$ \\
\hline $\mathrm{ROA}$ & & & & & $\begin{array}{c}3.933 * * * \\
(0.720)\end{array}$ & $\begin{array}{c}4.247 * * * \\
(0.718)\end{array}$ & $\begin{array}{c}4.260 * * * \\
(0.723)\end{array}$ & $\begin{array}{c}4.238 * * * \\
(0.725)\end{array}$ \\
\hline EstDate & & & & & & $\begin{array}{c}-0.001 \\
(0.001)\end{array}$ & $\begin{array}{l}-0.001 \\
(0.001)\end{array}$ & $\begin{array}{l}-0.001 \\
(0.001)\end{array}$ \\
\hline Size & & & & & & $\begin{array}{l}-0.033 \\
(0.027)\end{array}$ & $\begin{array}{l}-0.029 \\
(0.027)\end{array}$ & $\begin{array}{l}-0.033 \\
(0.027)\end{array}$ \\
\hline DirectorQual & & & & & & $\begin{array}{c}0.089 \\
(0.071)\end{array}$ & $\begin{array}{c}0.086 \\
(0.078)\end{array}$ & $\begin{array}{c}0.076 \\
(0.071)\end{array}$ \\
\hline HeadLondon & & & & & & $\begin{array}{c}-0.017 \\
(0.052)\end{array}$ & $\begin{array}{c}-0.026 \\
(0.051)\end{array}$ & $\begin{array}{l}-0.019 \\
(0.052)\end{array}$ \\
\hline Scottish & & & & & & $\begin{array}{c}-0.014 \\
(0.066)\end{array}$ & $\begin{array}{c}-0.016 \\
(0.068)\end{array}$ & $\begin{array}{c}-0.017 \\
(0.066)\end{array}$ \\
\hline LTDebt & & & & & & $\begin{array}{c}0.253 * * \\
(0.097)\end{array}$ & $\begin{array}{c}0.253 * * * \\
(0.097)\end{array}$ & $\begin{array}{c}0.250 * * \\
(0.097)\end{array}$ \\
\hline Constant & $\begin{array}{c}0.217 \\
(0.310)\end{array}$ & $\begin{array}{c}0.225 \\
(0.312)\end{array}$ & $\begin{array}{c}0.210 \\
(0.318)\end{array}$ & $\begin{array}{c}0.058 \\
(0.320)\end{array}$ & $\begin{array}{c}-0.018 \\
(0.291)\end{array}$ & $\begin{array}{c}2.682 \\
(2.705)\end{array}$ & $\begin{array}{c}2.599 \\
(2.625)\end{array}$ & $\begin{array}{c}2.554 \\
(2.727)\end{array}$ \\
\hline Year Dummies & YES & YES & YES & YES & YES & YES & YES & YES \\
\hline Observations & 212 & 212 & 212 & 212 & 193 & 192 & 191 & 192 \\
\hline R-squared & 0.094 & 0.094 & 0.092 & 0.145 & 0.374 & 0.409 & 0.415 & 0.410 \\
\hline
\end{tabular}

Notes: $* * * \mathrm{p}<0.01, * * \mathrm{p}<0.05, * \mathrm{p}<0.1$. Robust standard errors are in parentheses. Dependent variable is industry-adjusted Q. ROA is the industry-adjusted ROA. All outliers have been winsorized at the $1 \%$ and $99 \%$ levels. “" 
TABLE 8

ROA ROBUSTNESS TESTS - ALTERNATIVE DEFINITIONS OF LARGE BLOCKHOLDERS

\begin{tabular}{|c|c|c|c|c|c|c|}
\hline & \multicolumn{3}{|c|}{ Voting Concentration } & \multicolumn{3}{|c|}{ Capital Concentration } \\
\hline & $5 \%$ & $10 \%$ & $20 \%$ & $5 \%$ & $10 \%$ & $20 \%$ \\
\hline & $(1)$ & $(2)$ & $(3)$ & $(4)$ & $(5)$ & (6) \\
\hline \multirow[t]{2}{*}{ ActiveBlock } & $0.202 * * *$ & $0.285 * * *$ & $0.378 * *$ & $0.215^{* * *}$ & $0.300 * * *$ & $0.332 *$ \\
\hline & $(0.065)$ & $(0.095)$ & $(0.190)$ & $(0.079)$ & $(0.115)$ & $(0.177)$ \\
\hline \multirow[t]{2}{*}{ PassiveBlock } & 0.005 & -0.020 & -0.033 & -0.001 & -0.032 & -0.034 \\
\hline & $(0.027)$ & $(0.031)$ & $(0.032)$ & $(0.031)$ & $(0.036)$ & $(0.047)$ \\
\hline \multirow[t]{2}{*}{ DirOnlyVote } & -0.041 & 0.007 & 0.058 & 0.021 & 0.033 & $0.075^{*}$ \\
\hline & $(0.085)$ & $(0.048)$ & $(0.039)$ & $(0.082)$ & $(0.049)$ & $(0.041)$ \\
\hline \multirow[t]{2}{*}{ DirOnlyNum } & 0.000 & -0.000 & 0.000 & 0.000 & -0.000 & -0.000 \\
\hline & $(0.001)$ & $(0.001)$ & $(0.001)$ & $(0.001)$ & $(0.001)$ & $(0.001)$ \\
\hline \multirow[t]{2}{*}{ ActiveBlockSq } & $-0.316^{* * *}$ & $-0.513 * * *$ & $-0.782 * *$ & $-0.374 * *$ & $-0.591 * *$ & $-0.722 *$ \\
\hline & $(0.113)$ & $(0.180)$ & $(0.370)$ & $(0.173)$ & $(0.232)$ & $(0.382)$ \\
\hline \multirow[t]{2}{*}{ ActiveCashWedge } & $-0.181 *$ & -0.160 & $-0.148 *$ & -0.098 & -0.090 & $-0.132 *$ \\
\hline & $(0.103)$ & $(0.112)$ & $(0.083)$ & $(0.061)$ & $(0.068)$ & $(0.076)$ \\
\hline \multirow[t]{2}{*}{ DirFamily } & -0.007 & -0.009 & -0.006 & -0.007 & -0.011 & -0.011 \\
\hline & $(0.007)$ & $(0.008)$ & $(0.007)$ & $(0.008)$ & $(0.008)$ & $(0.009)$ \\
\hline \multirow[t]{2}{*}{ EstDate } & 0.000 & 0.000 & 0.000 & 0.000 & 0.000 & 0.000 \\
\hline & $(0.000)$ & $(0.000)$ & $(0.000)$ & $(0.000)$ & $(0.000)$ & $(0.000)$ \\
\hline \multirow[t]{2}{*}{ Size } & -0.000 & 0.000 & 0.001 & 0.000 & 0.001 & 0.001 \\
\hline & $(0.004)$ & $(0.004)$ & $(0.004)$ & $(0.004)$ & $(0.004)$ & $(0.004)$ \\
\hline \multirow[t]{2}{*}{ DirectorQual } & -0.003 & -0.005 & -0.001 & -0.004 & -0.005 & -0.001 \\
\hline & $(0.009)$ & $(0.009)$ & $(0.009)$ & $(0.009)$ & $(0.009)$ & $(0.009)$ \\
\hline \multirow[t]{2}{*}{ HeadLondon } & 0.007 & 0.007 & 0.005 & 0.008 & 0.007 & 0.008 \\
\hline & $(0.007)$ & $(0.006)$ & $(0.007)$ & $(0.007)$ & $(0.006)$ & $(0.007)$ \\
\hline \multirow[t]{2}{*}{ Scottish } & $0.019 * *$ & $0.017 * *$ & $0.017 * *$ & $0.020 * *$ & $0.017 *$ & $0.020 * *$ \\
\hline & $(0.008)$ & $(0.008)$ & $(0.008)$ & $(0.008)$ & $(0.008)$ & $(0.008)$ \\
\hline \multirow[t]{2}{*}{ LTDebt } & $-0.054 * * *$ & $-0.052 * * *$ & $-0.054 * * *$ & $-0.054 * * *$ & $-0.052 * * *$ & $-0.055 * * *$ \\
\hline & $(0.011)$ & $(0.012)$ & $(0.012)$ & $(0.011)$ & $(0.012)$ & $(0.012)$ \\
\hline \multirow[t]{2}{*}{ Constant } & -0.067 & -0.138 & -0.190 & -0.045 & -0.138 & -0.109 \\
\hline & $(0.399)$ & $(0.396)$ & $(0.405)$ & $(0.397)$ & $(0.395)$ & $(0.391)$ \\
\hline Year Dummies & YES & YES & YES & YES & YES & YES \\
\hline Observations & 221 & 221 & 221 & 221 & 221 & 221 \\
\hline R-squared & 0.233 & 0.239 & 0.235 & 0.228 & 0.244 & 0.232 \\
\hline
\end{tabular}

Notes: ${ }^{* * *} \mathrm{p}<0.01,{ }^{* *} \mathrm{p}<0.05,{ }^{*} \mathrm{p}<0.1$. Robust standard errors are in parentheses. Dependent variables are industryadjusted ROA and Q. All outliers have been winsorized at the $1 \%$ and $99 \%$ levels. 
TABLE 9

TOBIN'S Q ROBUSTNESS TESTS - ALTERNATIVE DEFINITIONS OF LARGE BLOCKHOLDERS

\begin{tabular}{|c|c|c|c|c|c|c|}
\hline & \multicolumn{3}{|c|}{ Voting Concentration } & \multicolumn{3}{|c|}{ Capital Concentration } \\
\hline & $5 \%$ & $10 \%$ & $20 \%$ & $5 \%$ & $10 \%$ & $20 \%$ \\
\hline & $(1)$ & $(2)$ & $(3)$ & $(4)$ & $(5)$ & $(6)$ \\
\hline ActiveBlock & $\begin{array}{c}0.141 \\
(0.770)\end{array}$ & $\begin{array}{c}0.190 \\
(1.401)\end{array}$ & $\begin{array}{c}0.457 \\
(1.781)\end{array}$ & $\begin{array}{l}-0.173 \\
(0.733)\end{array}$ & $\begin{array}{c}0.023 \\
(1.274)\end{array}$ & $\begin{array}{l}-0.108 \\
(1.437)\end{array}$ \\
\hline \multirow[t]{2}{*}{ PassiveBlock } & -0.105 & 0.041 & 0.160 & $-0.287 * *$ & -0.061 & 0.026 \\
\hline & $(0.156)$ & $(0.171)$ & $(0.165)$ & $(0.141)$ & $(0.175)$ & $(0.168)$ \\
\hline \multirow[t]{2}{*}{ DirOnlyVote } & -0.759 & -0.390 & -0.225 & -0.852 & -0.410 & -0.301 \\
\hline & $(0.778)$ & $(0.338)$ & $(0.400)$ & $(0.763)$ & $(0.381)$ & $(0.422)$ \\
\hline \multirow[t]{2}{*}{ DirOnlyNum } & $0.033 * * *$ & $0.032 * * *$ & $0.029 * * *$ & $0.032 * * *$ & $0.029 * * *$ & $0.031 * * *$ \\
\hline & $(0.011)$ & $(0.011)$ & $(0.010)$ & $(0.011)$ & $(0.009)$ & $(0.010)$ \\
\hline \multirow[t]{2}{*}{ ActiveBlockSq } & -0.353 & -0.637 & -1.831 & 0.163 & -0.573 & -0.392 \\
\hline & $(1.665)$ & $(3.009)$ & $(3.857)$ & $(1.629)$ & $(2.802)$ & $(3.171)$ \\
\hline \multirow[t]{2}{*}{ ActiveCashWedge } & -0.576 & -0.536 & -0.912 & -0.568 & -0.403 & -0.400 \\
\hline & $(1.555)$ & $(1.509)$ & $(1.262)$ & $(1.486)$ & $(1.452)$ & $(1.056)$ \\
\hline \multirow[t]{2}{*}{ DirFamily } & -0.044 & -0.048 & -0.047 & -0.031 & -0.028 & -0.036 \\
\hline & $(0.076)$ & $(0.099)$ & $(0.068)$ & $(0.074)$ & $(0.086)$ & $(0.069)$ \\
\hline \multirow[t]{2}{*}{ ROA } & $4.224 * * *$ & $4.247 * * *$ & $4.214 * * *$ & $4.293 * * *$ & $4.244 * * *$ & $4.313 * * *$ \\
\hline & $(0.706)$ & $(0.718)$ & $(0.732)$ & $(0.710)$ & $(0.733)$ & $(0.746)$ \\
\hline \multirow[t]{2}{*}{ EstDate } & -0.001 & -0.001 & -0.001 & -0.001 & -0.001 & -0.001 \\
\hline & $(0.001)$ & $(0.001)$ & $(0.001)$ & $(0.001)$ & $(0.001)$ & $(0.001)$ \\
\hline \multirow[t]{2}{*}{ Size } & -0.033 & -0.033 & -0.030 & -0.037 & -0.033 & -0.033 \\
\hline & $(0.028)$ & $(0.027)$ & $(0.027)$ & $(0.027)$ & $(0.026)$ & $(0.027)$ \\
\hline \multirow[t]{2}{*}{ DirectorQual } & 0.096 & 0.089 & 0.086 & 0.102 & 0.089 & 0.089 \\
\hline & $(0.069)$ & $(0.071)$ & $(0.073)$ & $(0.067)$ & $(0.069)$ & $(0.074)$ \\
\hline \multirow[t]{2}{*}{ HeadLondon } & -0.018 & -0.017 & -0.020 & -0.028 & -0.026 & -0.022 \\
\hline & $(0.052)$ & $(0.052)$ & $(0.052)$ & $(0.058)$ & $(0.055)$ & $(0.053)$ \\
\hline \multirow[t]{2}{*}{ Scottish } & -0.011 & -0.014 & -0.014 & -0.024 & -0.020 & -0.016 \\
\hline & $(0.064)$ & $(0.066)$ & $(0.066)$ & $(0.064)$ & $(0.067)$ & $(0.065)$ \\
\hline \multirow[t]{2}{*}{ LTDebt } & $0.246 * * *$ & $0.253 * *$ & $0.253 * * *$ & $0.237 * *$ & $0.243 * *$ & $0.249 * *$ \\
\hline & $(0.093)$ & $(0.097)$ & $(0.096)$ & $(0.094)$ & $(0.098)$ & $(0.096)$ \\
\hline \multirow[t]{2}{*}{ Constant } & 2.193 & 2.682 & 2.861 & 1.799 & 2.380 & 2.652 \\
\hline & $(2.708)$ & $(2.705)$ & $(2.716)$ & $(2.669)$ & $(2.686)$ & $(2.651)$ \\
\hline Year Dummies & YES & YES & YES & YES & YES & YES \\
\hline Observations & 192 & 192 & 192 & 192 & 192 & 192 \\
\hline R-squared & 0.411 & 0.409 & 0.410 & 0.417 & 0.411 & 0.409 \\
\hline
\end{tabular}

Notes: ${ }^{* * *} \mathrm{p}<0.01,{ }^{* *} \mathrm{p}<0.05,{ }^{*} \mathrm{p}<0.1$. Robust standard errors are in parentheses. Dependent variables are industryadjusted ROA and Q. 
TABLE 10

MULTINOMIAL LOGIT REGRESSIONS - FINAL STATUS OF THE COMPANY

\begin{tabular}{|c|c|c|c|c|c|}
\hline & $\begin{array}{c}(1) \\
\text { Merged }\end{array}$ & $\begin{array}{c}\text { (2) } \\
\text { CourtWoundUp }\end{array}$ & $\begin{array}{c}(3) \\
\text { Removed } \\
\end{array}$ & $\begin{array}{c}\text { (4) } \\
\text { VolWoundup } \\
\end{array}$ & $\begin{array}{c}(5) \\
\text { Reconstructed } \\
\end{array}$ \\
\hline VoteHHI & & $\begin{array}{c}0.193 \\
(0.253)\end{array}$ & $\begin{array}{l}-0.004 \\
(0.165)\end{array}$ & $\begin{array}{l}-0.329 * \\
(0.192)\end{array}$ & $\begin{array}{c}-0.332 \\
(0.210)\end{array}$ \\
\hline NumDir & & $\begin{array}{c}-0.538 * * * \\
(0.151)\end{array}$ & $\begin{array}{c}-0.361 * * * \\
(0.113)\end{array}$ & $\begin{array}{l}-0.106 \\
(0.086)\end{array}$ & $\begin{array}{c}-0.090 \\
(0.080)\end{array}$ \\
\hline OwnDate & & $\begin{array}{c}-0.136 * * * \\
(0.051)\end{array}$ & $\begin{array}{c}-0.090^{* * *} * \\
(0.028)\end{array}$ & $\begin{array}{c}-0.098 * * * \\
(0.029)\end{array}$ & $\begin{array}{c}-0.081 * * * \\
(0.026)\end{array}$ \\
\hline EstDate & & $\begin{array}{c}0.030 \\
(0.026)\end{array}$ & $\begin{array}{c}0.031^{*} \\
(0.016)\end{array}$ & $\begin{array}{c}0.052 * * * \\
(0.019)\end{array}$ & $\begin{array}{c}0.041 * * * \\
(0.014)\end{array}$ \\
\hline Size & & $\begin{array}{l}-0.019 \\
(0.319)\end{array}$ & $\begin{array}{l}-0.078 \\
(0.245)\end{array}$ & $\begin{array}{l}-0.061 \\
(0.208)\end{array}$ & $\begin{array}{l}-0.326 \\
(0.201)\end{array}$ \\
\hline DirectorQual & & $\begin{array}{c}-1.929^{*} \\
(0.984)\end{array}$ & $\begin{array}{l}-0.252 \\
(0.508)\end{array}$ & $\begin{array}{l}-0.441 \\
(0.456)\end{array}$ & $\begin{array}{c}0.224 \\
(0.380)\end{array}$ \\
\hline HeadLondon & & $\begin{array}{l}-0.904 \\
(0.767)\end{array}$ & $\begin{array}{l}-0.682 \\
(0.422)\end{array}$ & $\begin{array}{l}-0.056 \\
(0.420)\end{array}$ & $\begin{array}{l}-0.328 \\
(0.464)\end{array}$ \\
\hline Scottish & & $\begin{array}{c}1.779^{*} \\
(0.954)\end{array}$ & $\begin{array}{c}0.859 \\
(0.570)\end{array}$ & $\begin{array}{l}1.086^{*} \\
(0.568)\end{array}$ & $\begin{array}{c}0.459 \\
(0.611)\end{array}$ \\
\hline Constant & & $\begin{array}{c}202.815^{* *} \\
(95.166)\end{array}$ & $\begin{array}{c}114.369^{* *} \\
(48.214)\end{array}$ & $\begin{array}{l}86.636 * * \\
(43.523)\end{array}$ & $\begin{array}{l}77.811^{*} \\
(44.957)\end{array}$ \\
\hline Industry Dummies & & Yes & Yes & Yes & Yes \\
\hline Observations & 294 & 294 & 294 & 294 & 294 \\
\hline
\end{tabular}


TABLE 11

MULTINOMIAL LOGIT REGRESSIONS - FINAL STATUS OF THE COMPANY, DISTINGUISHING THE INTERACTION BETWEEN LARGE BLOCKHOLDERS AND DIRECTORS

\begin{tabular}{|c|c|c|c|c|c|}
\hline & $\begin{array}{c}(1) \\
\text { Merged }\end{array}$ & $\begin{array}{c}\text { (2) } \\
\text { CourtWoundUp }\end{array}$ & $\begin{array}{c}(3) \\
\text { Removed }\end{array}$ & $\begin{array}{c}\text { (4) } \\
\text { VolWoundup }\end{array}$ & $\begin{array}{c}(5) \\
\text { Reconstructed } \\
\end{array}$ \\
\hline ActiveBlock & & $\begin{array}{c}-4.652 * \\
(2.664)\end{array}$ & $\begin{array}{c}-2.109 * \\
(1.182)\end{array}$ & $\begin{array}{l}-2.114 \\
(2.026)\end{array}$ & $\begin{array}{l}-1.091 \\
(1.387)\end{array}$ \\
\hline PassiveBlock & & $\begin{array}{l}-0.820 \\
(2.134)\end{array}$ & $\begin{array}{c}-1.784 \\
(1.654)\end{array}$ & $\begin{array}{l}-1.930 \\
(1.396)\end{array}$ & $\begin{array}{l}-1.779 \\
(2.257)\end{array}$ \\
\hline DirOnlyVote & & $\begin{array}{l}8.760 * \\
(4.829)\end{array}$ & $\begin{array}{l}-0.819 \\
(3.115)\end{array}$ & $\begin{array}{c}0.307 \\
(3.311)\end{array}$ & $\begin{array}{l}-2.441 \\
(3.343)\end{array}$ \\
\hline DirOnlyNum & & $\begin{array}{c}-0.643 * * * \\
(0.163)\end{array}$ & $\begin{array}{c}-0.391 * * * \\
(0.116)\end{array}$ & $\begin{array}{l}-0.086 \\
(0.092)\end{array}$ & $\begin{array}{l}-0.053 \\
(0.080)\end{array}$ \\
\hline DirFamily & & $\begin{array}{l}-0.193 \\
(0.741)\end{array}$ & $\begin{array}{c}0.037 \\
(0.476)\end{array}$ & $\begin{array}{l}-0.787 \\
(0.765)\end{array}$ & $\begin{array}{c}-1.462 \\
(0.896)\end{array}$ \\
\hline OwnDate & & $\begin{array}{c}-0.132 * * * \\
(0.048)\end{array}$ & $\begin{array}{c}-0.090 * * * \\
(0.028)\end{array}$ & $\begin{array}{c}-0.093 * * * \\
(0.029)\end{array}$ & $\begin{array}{c}-0.077 * * * \\
(0.026)\end{array}$ \\
\hline EstDate & & $\begin{array}{c}0.038 \\
(0.027)\end{array}$ & $\begin{array}{c}0.035^{* *} \\
(0.017)\end{array}$ & $\begin{array}{c}0.051 * * * \\
(0.019)\end{array}$ & $\begin{array}{c}0.041 * * * \\
(0.014)\end{array}$ \\
\hline Size & & $\begin{array}{c}0.071 \\
(0.310)\end{array}$ & $\begin{array}{l}-0.040 \\
(0.247)\end{array}$ & $\begin{array}{l}-0.020 \\
(0.207)\end{array}$ & $\begin{array}{l}-0.302 \\
(0.200)\end{array}$ \\
\hline DirectorQual & & $\begin{array}{c}-1.880 * * \\
(0.948)\end{array}$ & $\begin{array}{l}-0.227 \\
(0.535)\end{array}$ & $\begin{array}{l}-0.466 \\
(0.446)\end{array}$ & $\begin{array}{c}0.272 \\
(0.353)\end{array}$ \\
\hline HeadLondon & & $\begin{array}{l}-0.580 \\
(0.809)\end{array}$ & $\begin{array}{l}-0.651 \\
(0.433)\end{array}$ & $\begin{array}{l}-0.153 \\
(0.429)\end{array}$ & $\begin{array}{l}-0.487 \\
(0.459)\end{array}$ \\
\hline Scottish & & $\begin{array}{l}1.897^{*} \\
(1.081)\end{array}$ & $\begin{array}{c}0.957^{*} \\
(0.582)\end{array}$ & $\begin{array}{l}0.987^{*} \\
(0.584)\end{array}$ & $\begin{array}{c}0.281 \\
(0.621)\end{array}$ \\
\hline Constant & & $\begin{array}{c}178.053 * * \\
(90.240)\end{array}$ & $\begin{array}{c}105.939 * * \\
(48.119)\end{array}$ & $\begin{array}{l}78.952 * \\
(43.365)\end{array}$ & $\begin{array}{c}71.168 \\
(44.427)\end{array}$ \\
\hline Industry Dummies & & Yes & Yes & Yes & Yes \\
\hline Observations & 294 & 294 & 294 & 294 & 294 \\
\hline
\end{tabular}


APPENDIX 1

COMPARISON OF SAMPLE DATA TO INVESTOR'S MONTHLY MANUAL DATA

\begin{tabular}{|c|c|c|c|c|c|c|c|c|c|c|c|c|}
\hline & \multicolumn{3}{|c|}{ Performance Data } & \multicolumn{3}{|c|}{ Final Status Data } & \multicolumn{3}{|c|}{$\operatorname{IMM}(1880)$} & \multicolumn{3}{|c|}{$\operatorname{IMM}(1900)$} \\
\hline & $\mathrm{N}$ & $\%$ & $\begin{array}{c}\text { Median } \\
\text { Par Value }\end{array}$ & $\mathrm{N}$ & $\%$ & $\begin{array}{c}\text { Median } \\
\text { Par Value }\end{array}$ & $\mathrm{N}$ & $\%$ & $\begin{array}{c}\text { Median } \\
\text { Par Value }\end{array}$ & $\mathrm{N}$ & $\%$ & $\begin{array}{c}\text { Median } \\
\text { Par Value }\end{array}$ \\
\hline Banks & 39 & 15.5 & 274,700 & 49 & 14.2 & 228,568 & 168 & 20.4 & 300,000 & 133 & 10.5 & 412,773 \\
\hline Breweries & 3 & 1.2 & 139,880 & 17 & 4.9 & 219,820 & 5 & 0.6 & 340,000 & 115 & 9.1 & 266,670 \\
\hline Gas, Light \& Coke & 11 & 4.4 & 147,900 & 15 & 4.4 & 130,000 & 61 & 7.4 & 200,000 & 71 & 5.6 & 350,000 \\
\hline Industrial \& Commercial & 65 & 25.8 & 145,075 & 117 & 34.0 & 103,883 & 187 & 22.7 & 106,700 & 412 & 32.6 & 200,000 \\
\hline Insurance & 16 & 6.3 & 100,000 & 14 & 4.1 & 99,997 & 97 & 11.8 & 100,000 & 87 & 6.9 & 120,000 \\
\hline Iron,Coal \& Steel & 31 & 12.3 & 155,860 & 24 & 7.0 & 149,000 & 59 & 7.2 & 210,000 & 93 & 7.4 & 240,000 \\
\hline Mines & 10 & 4.0 & 110,857 & 19 & 5.5 & 73,230 & 77 & 9.4 & 100,000 & 157 & 12.4 & 242,000 \\
\hline Mortgage \& Finance & 35 & 13.9 & 130,731 & 42 & 12.2 & 100,000 & 57 & 6.9 & 112,500 & 94 & 7.4 & 361,930 \\
\hline Steamships & 14 & 5.6 & 134,913 & 15 & 4.4 & 188,440 & 39 & 4.7 & 200,000 & 39 & 3.1 & 466,420 \\
\hline Telegraph & 8 & 3.2 & 287,513 & 10 & 2.9 & 200,000 & 20 & 2.4 & 436,600 & 19 & 1.5 & 800,000 \\
\hline Tramways & 13 & 5.2 & 122,028 & 14 & 4.1 & 104,662 & 30 & 3.6 & 135,000 & 31 & 2.5 & 270,000 \\
\hline Wagon & 7 & 2.8 & 121,232 & 8 & 2.3 & 90,619 & 22 & 2.7 & 109,650 & 13 & 1.0 & 125,436 \\
\hline Total & 252 & 100.0 & 150,000 & 344 & 100.0 & 133,099 & 822 & 100.0 & 150,000 & 1,264 & 100.0 & 250,000 \\
\hline
\end{tabular}

Notes: Performance Data and Final Status Data shows the frequency of observations from each industry, and the median par value of equities and preference shares issued by those companies. Investor's Monthly Manual (IMM) data shows the par value of equities and preference shares issued by non-railway corporations in 1880 and 1900 . It does not include the value of corporate bonds, government bonds, railway securities or investment trusts. 
APPENDIX 2

\section{VARIABLE DEFINITIONS AND SOURCES}

\begin{tabular}{|c|c|c|}
\hline Variable & Description & Data sources \\
\hline \multicolumn{3}{|l|}{ Ownership variables } \\
\hline VoteLargest5 & Percentage of votes controlled by five largest shareholders & OR, AoA, SEOI, BOI \\
\hline VoteHHI & Herfindhal Index of voting rights (\%) & OR, AoA, SEOI, BOI \\
\hline VoteDir & Percentage of votes controlled by individuals who were directors & OR, AoA, SEOI, BOI \\
\hline VoteInsiders & Percentage of votes controlled by directors and large blockholders & OR, AoA, SEOI, BOI \\
\hline ActiveBlock & $\begin{array}{l}\text { Percentage of votes controlled by individuals who were directors and large } \\
\text { blockholders }\end{array}$ & OR, AoA, SEOI, BOI \\
\hline ActiveBlockSq & ActiveBlock squared & \\
\hline ActiveCEOBlock & $\begin{array}{l}\text { Percentage of votes controlled by individuals who were CEOs and large } \\
\text { blockholders }\end{array}$ & OR, AoA, SEOI, BOI \\
\hline ActiveCEOBlockSq & ActiveCEOBlock squared & \\
\hline ActiveNotCEOBlock & $\begin{array}{l}\text { Percentage of votes controlled by individuals who were directors and large } \\
\text { blockholders but not CEOs }\end{array}$ & OR, AoA, SEOI, BOI \\
\hline ActiveNotCEOBlockSq & ActiveNotCEOBlock squared & \\
\hline PassiveBlock & $\begin{array}{l}\text { Percentage of votes controlled by individuals who were solely large } \\
\text { blockholders }\end{array}$ & OR, AoA, SEOI, BOI \\
\hline DirOnlyVote & $\begin{array}{l}\text { Percentage of votes controlled by individuals who were directors but not } \\
\text { blockholders }\end{array}$ & OR, AoA, SEOI, BOI \\
\hline \multicolumn{3}{|l|}{ Directors } \\
\hline NumDir & Board size & AoA, SEY, SEOI, BOI \\
\hline DirOnlyNum & Number of directors who were not large shareholders & AoA, SEY, SEOI, BOI \\
\hline PropDirBlock & Proportion of board which are active blockholders & AoA, SEY, SEOI, BOI \\
\hline DirFamily & The number of directors with the same surname as a blockholder & AoA, SEY, SEOI, BOI \\
\hline \multicolumn{3}{|l|}{$\underline{\text { Performance variables }}$} \\
\hline ROA & Return on assets $(\%)$ & BCCA \\
\hline Q & Tobin's Q & BCCA, IMM \\
\hline Merged & A binary variable $=1$ if firm merged into another firm, 0 otherwise & RDC, EG, LG \\
\hline CourtWoundUp & A binary variable $=1$ if firm was wound up by court order, 0 otherwise & RDC, EG, LG \\
\hline Removed & A binary variable $=1$ if firm has been removed from SEY, 0 otherwise & RDC, EG, LG \\
\hline VolWoundUp & A binary variable $=1$ if firm was voluntarily wound up, 0 otherwise & RDC, EG, LG \\
\hline Reconstructed & A binary variable $=1$ if firm was reconstructed, 0 otherwise & RDC, EG, LG \\
\hline \multicolumn{3}{|l|}{ Control variables } \\
\hline OwnDate & Year in which ownership census was taken & OR \\
\hline EstDate & Year in which company was established & AoA, SEY, SEOI, BOI \\
\hline Size & Natural log of company par (paid-up) value & OR, SEY, SEOI, BOI \\
\hline DirectorQual & Shareholding requirement for directors scaled by total paid-up capital & AoA, SEY, SEOI, BOI \\
\hline HeadLondon & $\begin{array}{l}\text { A binary variable which equals } 1 \text { if company has a head office in London, } 0 \\
\text { otherwise }\end{array}$ & AoA, SEY, SEOI, BOI \\
\hline Scottish & A binary variable which equals 1 if company is Scottish, 0 otherwise & OR \\
\hline LTDebt & Long-term debt as a percentage of total capital & BCCA, IMM \\
\hline ActiveCashWedge & Proportion of capital owned minus votes controlled by active blockholders & OR, AoA, SEOI, BOI \\
\hline VoteNonLinear & $\begin{array}{l}\text { A binary variable }=1 \text { if each share did not have equal voting rights, } 0 \\
\text { otherwise }\end{array}$ & OR, AoA, SEOI, BOI \\
\hline Uncalled & Difference between the nominal and par value of a share & OR, AoA, SEOI, BOI \\
\hline
\end{tabular}

Notes: $\mathrm{AoA}=$ Articles of Association; BCCA = Burdett's Collection of Company Accounts at the Guildhall Library; BOI = Burdett's Official Intelligence; EG = Edinburgh Gazette: LG = London Gazette; IMM = Investor's Monthly Manual; OR = ownership returns from national archives; RDC $=$ Register of Defunct Companies; SEOI = Stock Exchange Official Intelligence; SEY $=$ Stock Exchange Yearbook. 